\title{
MANUFACTURE OF INDIRECT SOLAR DRYER FROM SOME LOCAL MATERIAL TO DRY APRICOTS
}

\author{
Hanafy W. M. * and Tarabye H. H. H. *
}

\begin{abstract}
In the present work, a new special, prototype of an indirect solarelectrical dryer for agricultural products was set up and also tested at Faculty Of Agricultural \& Natural Resources, Aswan University, Egypt.The main objective of the study was to transform some local materials unbeneficial to useful components and reuse it to fabricte an indirect solar-electrical dryer.Apricots were studied with different temperatures and velocities of drying air to study the influence of these parameters on the removal moisture content from the product and their effective moisture diffusivity to determine their suitable values. In order to estimate and select the suitable form of solar drying curves, five different mathematical models, were compared according to their coefficient of determination $R^{2}, M B E, R M S E, E \%$ and chi square $X^{2}$ to estimate experimental drying curves. The Page model in this condition proved to be the best for predicting drying behavior of apricots slice with $\left(R^{2}=\right.$ 0.9968, $X^{2}=0.000068$ ). The effective moisture diffusivity (Deff) was obtained using Fick's diffusion equation and its mean values ranged between $1.94 \times 10^{-5}$ and $3.19 \times 10^{-5} \mathrm{~m}^{2} / \mathrm{s}$ for all investigated conditions. Average activation energy increased with the decrease of $I R$ radiation and increase of air flow velocity. Thermal behavior of dryer and the effect of high air mass flow on the collector and system drying efficiency were compared. These results showed that the percentage of collector efficiency ranged from (13.28 to 36.55),(15.82 to 48.28) and (37.83 to $64.49) \%$ while the effectivness were ranged from (11.26 to 64.97), (18.69 to 68.58) and (22.11 to 56.80) in addition to that the percentage of dryer efficiency ranged from (22.42 to 60.43),(12.69 to 57.43) and (15.14 to 60.24) while the effectiveness were ranged from (20.37 to 58.69), and (24.82 to 70.96) for exhusted fan speed 1.5, 2.2 and $3 \mathrm{~m} / \mathrm{s}$ respectively.
\end{abstract}

\footnotetext{
*Lecturer, of Ag. Eng.and Bio System. Dept., Faculty of Agric.and Natural Resources, Aswan University.
} 
The highest collector efficiency were acompanied with speed $3 \mathrm{~m} / \mathrm{s}$ while it acompanied with speed 2.2 for dryer. The calculated value of the moisture diffusivity varied from $1.94708 \times 10^{-5}$ to $3.01943 \times 10^{-5} \mathrm{~m}^{2} / \mathrm{s}$ for apricot fruit. And the value of activation energy ranged from 34.35 to $71.12 \mathrm{~kJ} / \mathrm{mol}$ at different velocities of air.Finally an economic evaluation was calculated using the criterion of payback period which is found very small 1.22 years compared to the life of the dryer 25 years.

Key words: Solar drying, Drying models, Apricots, Effective diffusivity, activation energy, efficiency, effectivness.

\section{INTRODUCTION}

$\mathrm{N}$ owadays, solar crop dryers seems to be a perfect way to lower mass for agricultural products compared to traditional drying methods. In light of the current rising in energy prices and the cost of setting up solar dryers. This work presents an unconventional idea by transform some local materials unbeneficial to indirect solar dryer and improves the quality of drying apricots. This new configuration presents some advantages. firstly, reuse some some local materials to construct indirct solar dryer with low costs Secondly, Loading product in dryer shelfs and unloading is easy in addition this protype suitble to drying anymore agro-products with a hight quality.

Can (2000) indicated that drying process takes place in two stages. first happens on the surface of drying material with a constant drying rate and is like to vaporization of water into the ambient air while the second takes place by decreasing drying rate.

Mrittika et al. (2000) pointed that emperical model gives a relation between average moisture and drying time, whereas theoretical model takes into the geometry of the product, its mass diffusivity and conductivity. Semi-theoretical models are derived from Fick's second law of diffusion, such as Page model, Henderson and Pabis model, Two-term model, Logarithmic model and Midilli et al.

Basunia and Abe (2001) said that the major objective in drying agricultural products is the reduction of the moisture content to a level which allows safe storageover an extended period. Also, it brings about 
substantial reduction in weight and volume, minimizing packaging, storage and transportation costs.

Yilbas et al. (2003) indicated that drying of moist products is a complex process comprising coinciding heat and mass transfer.The practice of drying a product sample in a single layer is known as thin-layer drying .Three types of mathematical models are used to define thin-layer drying process theoretical models study the internal resistance for transferring the moisture between heating air, semi-theoretical and experimental models which only take into account the external resistance.

Kudra (2004) reported that solar natural drying was used to drying agroproduct in ancient times however, unprotected from rain, storm, windborne dirt, dust, and infestation by insects and rodents. quality of food can be seriously degraded so it sometimes becomes inedible while artificial dryer become a more suitable alternative because it can reduce agro-products losses, improve the quality of dried product significantly and is economically beneficial compared to solar drying methods.

Akpinar et al.(2006). found that a model is considered more suitable the higher values of $\mathrm{R}^{2}$ and the lower the values of $\mathrm{x}^{2}$, RMSE and $\mathrm{E} \%$.

Doymaz (2007) said that drying consider oldest methods for food preservation.

Celma et al., (2008). highlighted that mathematical modeling is the best and appropriate approach for describing the kinetics of the drying process. the behavior of drying of agricultural products requires specific correlation and regression statistical methods give an accurate explanation of the process.

Edoun et al. (2013) reported that drying process takes place in closed equipment improved the quality of the final product.

Milczarek et al.(2014) said that sun drying time for apricots ranged from 1 to 2 days. They improve drying of apricots with Photo-Selective Dryer Cabinet Materials.The air drying forced by suction of anexhaust fan enters from the collector to the bottum of dryer passed through products on the trays then getout from the top of the dryer furthermore, varius air flow rate between 0.026 and $0.053 \mathrm{~m}^{3} / \mathrm{s}$, to study the influence of high air flow rate on the process of drying. 
Amer and Amer Eissa (2015) carried out some experiments on Navel and Minneola orange slices at different thickness of 3,6 and $9 \mathrm{~mm}$ were dried using a forced air solar dryer and have been examined nine drying models defining thin layer drying behavior of it using statistical analysis. The results showed the drying rate was decreased during the drying time and for increasing drying rate, orange could be sliced to $3 \mathrm{~mm}$.

Donka et al.(2017) carried out some experiments on apricot were conducted at temperature of $(\mathrm{T}=50-80)^{\circ} \mathrm{C}$ and air velocity of $(v=0.5-2) \mathrm{m} / \mathrm{s}$ of the drying agent.The results cleared that the optimal values of the temperature and velocity of the drying agent according the criteria for the quality of the final product, the process duration and the energy consumption are $\mathrm{T}=63.5^{\circ} \mathrm{C}$ and $\mathrm{V}=0.5 \mathrm{~m} / \mathrm{s}$.

The research was conducted to prduce drying apricots under various air temprature and air flow rate. The goal of this research is also to determine the efficiency and effectivness of the solar collector and dryer under three various air mass flow rates. The hightest value of collector and dryer efficiency and effectivness will apper and accombiend with the best air mass flow rate during thin layer drying process of apricots.

To achieve this aim the following was carried out.

1- Testing of an indirect solar-electrical dryer in summer season with out load.

2- Development of mathematical modeling of thin layer forced solar drying.

3- Determination the effective diffusivities and activation energies of the apricots samples of apricots from the drying data.

4- Compare the energy efficiency and effectivness of the system under various air mass flow rate ranged from $(0.026 \sim 0.053) \mathrm{m} 3 / \mathrm{s}$.

5 - Determination the effective diffusivities and activation energies of the apricots samples of apricots from the drying data.

6- Calculate earnings from the solar- electrical dryer and economical evaluation.

from the drying data presented in the results pointing to the fit thin layer model in addition, the effective diffusivities, activation energies and behavior of solar-electrical dryer. 


\section{MATERIALS AND METHODS}

Experiments were carried out during the month of May, 2018 in Aswan City, Egypt. (longitude $(\Phi)=20^{\circ} 0524 \mathrm{~N}$ and latitude $(\lambda)=59^{\circ} 5332 \mathrm{E}$ ). The drying of apricot was examined in the indirect forced convection solar- electrical constructed and installed at a Faculty Of Agricultural \& Natural Resources, Aswuan University in Aswan City, Egypt. The experiments started at 8:00 am and terminated at 5:00 pm. It was installed in an environment with air relative humidity of (20 32)\%, ambient air speed of $(0.8 \sim 2.8) \mathrm{m} / \mathrm{s}$ and ambient air temperature varied from 37 to $49^{\circ} \mathrm{C}$. During the experiments, the ambient temperature, relative humidity, and inlet and outlet temperatures of air in the solar collector and dryer chamber were recorded. Solar collector and - dryer were installed on a raised far from the shade of buildings during the whole duration of the system trial.

\section{The basic components of the dryer fig (1):-}

\section{1- Flat plate solar collector:-}

The solar air collector is made from a metal cupboard of local materials with a thickness of $0.001 \mathrm{~m}$ and shelves, doors and the empty structure were removed and painted matte black not shiny to absorb most of the incident solar radiation. The top losses are minimized by placing a glass cover of $0.005 \mathrm{~mm}$ thickness over the top of the collector while the wood panels sheets is used as a sides and an insulation layer of sawdust sandwiched between two parallel galvanized metal sheet and wood panels sheet is used as sides and back insulator. The solar air collector insulated with a sawdust thickness $0.025 \mathrm{~m}$ from the sides of the collector and $0.05 \mathrm{~m}$ from the bottom of collector walls of dimensions $(1.95 \times 0.90 \times 0.45) \mathrm{m}$ (height, width and depth) and has an area of $1.755 \mathrm{~m}^{2}$ is inclined at an angle of $5^{\circ} 0524 \mathrm{~N}$ (latitude of Aswan city) with the horizontal facing south all the time. There is one opening in the front of collector to enter ambient air and another one in the back to allow hot exhusted air from the collector pass to dryer throught a plastic tube isolated by a layer of fiber glasses. There is a distance of $0.45 \mathrm{~m}$ as air gap between the glasses cover and the absorbing black galvanized metal plate. 


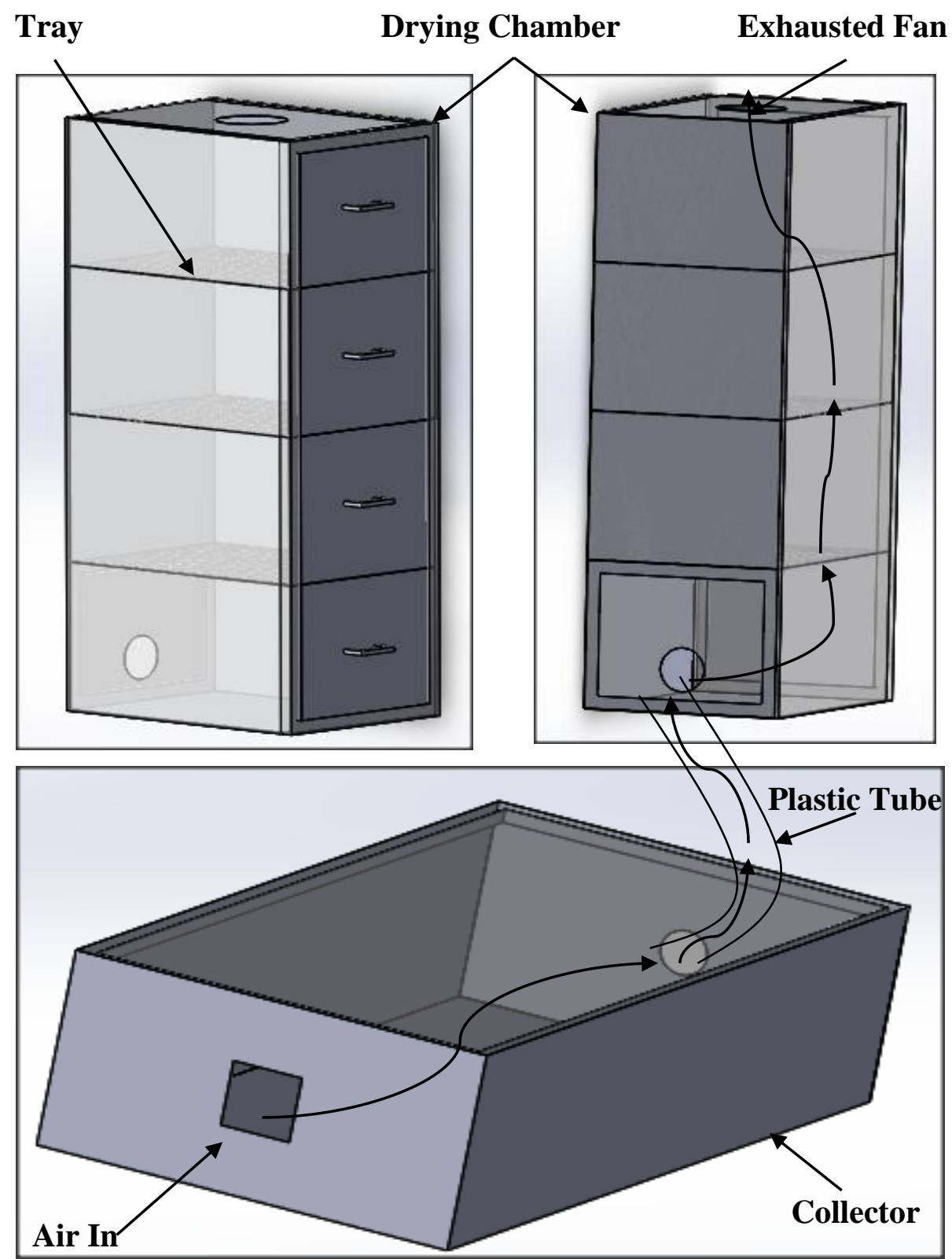

Fig. (1): A Schematic view of solar collector \& drying chamber components.

Ambient air enter the solar collector through the front duct while the absorber metal plate heated by absorbing the solar radiation and transferred the heat to the ambient air and this air absorbing the heat and 
the air was drawn under the glass sheet, between the glass and the absorber.

\section{2- drying chamber:-}

The drying chamber fabricated from an old vertica filing cabinet has four drawers with a thickness of $0.001 \mathrm{~m}$ where the base of the first three drawers was removed and replaced with a wire mesh shelfs, to putting the product on it. The drying cabinet galvanized iron box walls of dimension $(1.37 \times 0.63 \times 0.45) \mathrm{m}$ (height, width and depth) insulated by placing a wood panels sheets is used as a sides and an insulation layer of sawdust sandwiched between two parallel galvanized metal sheet and wood panels sheet is used as sides and back insulator while the outer drawers walls insulated by a fiber glasses with a thickness $0.025 \mathrm{~m}$ from the sides and $0.05 \mathrm{~m}$ from the top and the bottom of cabinet. The drying chamber provied with a duct from behind to enter hot ambient air coming from the collector and electrical exhusted fan put on the the top of cabinet with diameter $15 \mathrm{~cm}$ model $\mathrm{MH}-15 \mathrm{G}$ power in put 16 watt, running at $1560 \mathrm{rpm} /$ minute.Heated air move by forced suction of electrical exhausted fan to the drying chamber of apricots from behind duct through a plastic tube. A thermal performance analysis run to the solar collector and dryer without load under different air speed were 1.5, 2.2 and $3 \mathrm{~m} / \mathrm{s}$ controlled manually by electrical resistance to change air velocity.

\section{3- wooden installation frame:-}

Solar dryer was placed on a raised wooden fram while the solar collector its fram allow to rotating around the axis of its fixation to change the angle of inclination as aseason and the city location.

\section{4- Sample preparation:-}

Fresh apricots were purchased from the local market, chosen without blemish and with similar size and colour.A kilogram of apricots was washed before to their drying, Divided into four parts and remove the seed away. The apricots sample was weighed using an electronic balance every 30 minute time interval throughout the drying period. Weights and average temperature were recorded on the three shelves for each fan speed. 


\section{METHDOLOGY:-}

The apricots Sun drying was particularly achieved by simulating two existing ways of drying. The first way, the drying with forced convection, was in the solar assisted dryer in middle summer with a maximum and minimum ambient air temperature of around $37 \approx 49^{\circ}$ Cover one-day drying cycle with relatively low air humidity, which never exceed 25 per cent while the other way open air-sun drying. The Sun drying took place by putting about $200 \mathrm{~g}$ of apricots on each shelf of the dryer and left to dry while $200 \mathrm{~g}$ of apricots spread in on the ground and left to natural convection by open sun-light, under solar radiation changing between 277 and $1055 \mathrm{~W} / \mathrm{m}^{2}$. Before the drying experiments, initial moisture contents of apricots samples were determined as follows: using electric balance before and after drying each treatment about $200 \mathrm{~g}$ raw weight of apricots were placed on electrical oven at $78^{\circ} \mathrm{C}$ during $48 \mathrm{~h}$ even weight stability, three replicates carried out for sample according to the Association of Official Analytical (AOAC, 2005).The drying process was terminated when the moisture content decreased to about $12 \%$ wet basis (wb) from the initial moisture content value of $88.5 \%$ wet basis (wb).

\section{Mathematical modeling of solar drying kinetics for apricots.}

1-Moisture content (\%):- It can be calculated as follows: (Tayel et al., 2012 and Hassan, 2015).

$$
\text { M.C. (w. b.) } \%=\frac{(\mathrm{W}-\mathrm{D})}{\mathrm{W}} \times 100
$$

2-Desired final weight: - However, this desired final weight of dry apricots was calculated as follows, (Brennand, 1994).

$$
\text { Desired dry Wt. }(\mathrm{g})=\frac{(\text { Raw Wt. g) (Solids \%) }}{90 \%} \longrightarrow
$$

In this research, the solids in the raw apricots is about $12 \%$, so according to Eq. (2), the desired dry weight of apricots during drying will be above $27 \mathrm{~g}$. of $200 \mathrm{~g}$ raw weight.

3-Moisture content (dry basis), (M.C. d.b ):- The moisture contents were converted to dry basis using the following equation, (Fadhel et al. 2014).

$$
\mathrm{MC}(\text { d.b. }) \%=\frac{\text { M.C.(W.b. }) \%}{100-\text { M.C }(\text { W.b })} \times 100
$$


4- Drying rate (DR):- Where the drying rate, DR, is expressed as the amount of the evaporated moisture over time (g water/g dry matter .sec) and express by the Arrhenius relationship (Premi, et al. 2010).

$$
D R=\frac{(M t+d t)-M t}{D t}
$$

5-Evaporating rate: - The evaporating rate is expressed as the amount of the evaporated moisture over time ( $\mathrm{g}$ water/min) by the following relationship.

$$
\mathrm{ER}=\frac{(\mathrm{Wt}+\mathrm{dt})-\mathrm{Wt}}{\mathrm{Dt}} \longrightarrow
$$

6-Drying ratio:- The drying ratio calculated from the following mathematical formula.

$$
\mathrm{DR}=\frac{\mathrm{D}}{\mathrm{W}}
$$

Simulation of the Drying Data: The obtained data of the experiments were employed to investigate the applicability of the five studied thin layer drying models (Lewis's 1921, Page1949, Modified page1981, Modified page II 1991and Henderson and Pabis1961) The examined drying models could be presented in table (1).

Table (1) Models used to describe the thin-layer drying curve.

\begin{tabular}{|c|c|c|c|}
\hline NO & Model name & Analytical expression & Reference \\
\hline 1 & Lewis & MR $=\exp \left(-\mathrm{k}_{\mathrm{L}} \mathrm{t}\right)$ & Bruce $(1985)$ \\
\hline 2 & Page & $\mathrm{MR}=\exp \left(-\mathrm{k}_{\mathrm{P}} \mathrm{t}^{\mathrm{n}}\right)$ & Page $(1949)$ \\
\hline 3 & Modified page & $\mathrm{MR}=\exp \left(-\mathrm{k}_{\mathrm{M}} \mathrm{t}\right)^{\mathrm{n}}$ & White et al. (1981) \\
\hline 4 & Modified page II & $\mathrm{MR}=\exp \left(-\mathrm{k}(\mathrm{t} / \mathrm{L} 2)^{\mathrm{n}}\right)$ & Diamante and Munro (1991) \\
\hline 5 & Henderson and Pabis & $\mathrm{MR}=\mathrm{a} \exp \left(-\mathrm{k}_{\mathrm{H}} \mathrm{t}\right)$ & Henderson and Pabis (1961) \\
\hline
\end{tabular}

1-The values of the drying constant $\left(\mathrm{k}_{\mathrm{L}}\right)$ for the Lewis's model (1) could be obtained from the relationship between the natural logarithm Ln (MR) of the tested sample versus the drying time ( $t$ ) as follows:

$\operatorname{Ln} M R=-k_{L} t$

2- Page's model determined by plotting the values of Ln (-Ln (MR)) versus the drying time $(\operatorname{Ln}(t))$ as follows formula:

$(\operatorname{Ln}(-\operatorname{Ln}(\mathrm{MR})))=\operatorname{Ln}\left(\mathrm{k}_{\mathrm{P}}\right)+\mathrm{n} \operatorname{Ln}(\mathrm{t})$ $(8)$ 
3- Modified page determined after plotting the values of $\operatorname{Ln}(-\operatorname{Ln}(\mathrm{MR})$ ) versus the drying time $(\operatorname{Ln}(\mathrm{t}))$ simplified as:

$(\operatorname{Ln}(-\operatorname{Ln}(\mathrm{MR})))=\mathrm{n} \operatorname{Ln} \mathrm{k}_{\mathrm{M}}+\mathrm{n} \operatorname{Ln} \mathrm{t}$

4- Modified page II determined after plotting the values of $\operatorname{Ln}(-\operatorname{Ln}(\mathrm{MR}))$ versus the drying time $\left(\operatorname{Ln}\left(\mathrm{t} / \mathrm{L}^{2}\right)\right)$ as following:

$(\operatorname{Ln}(-\operatorname{Ln}(\mathrm{MR})))=\operatorname{Ln} \mathrm{K}_{\mathrm{H}}+\mathrm{n} \operatorname{Ln}\left(\mathrm{t} / \mathrm{L}^{2}\right)$

5- Henderson and Pabis obtained from the relationship between Ln (MR) versus the drying time $(\mathrm{t})$ found as:

5- $\mathrm{Ln} \mathrm{MR}=\mathrm{Ln} \mathrm{a}-\mathrm{k}_{\mathrm{H}} \mathrm{t}$

The drying constant (a) represented by the curve slope while, the constant $\left(\mathrm{k}_{\mathrm{H}}\right)$ represented by the $\mathrm{y}$-intercept.

\section{Correlation coefficient and error analysis:-}

The coefficient of determination $\left(\mathrm{R}^{2}\right)$, reduced chi-square $\left(\boldsymbol{X}^{2}\right)$, root mean square error (RMSE) and the average percentage error (E\%) were used to inspect the good fitness of the selected mathematical models to the experimental data. A model is considered more suitable the higher values of $\mathrm{R}^{2}$ and the lower the values of $\boldsymbol{X}^{2}$, RMSE and E\% (Gunhan et al., 2005; Akpinar et al., 2006).

The following equations were used to calculate the abovementioned parameters:

$$
\begin{aligned}
\mathrm{R}^{2} & =1-\left[\frac{\sum\left(\mathrm{MR}_{\operatorname{Prd}}-\sum \mathrm{MR}_{\operatorname{Exp}}\right)}{\sum\left(\overline{\mathrm{MR}}_{\operatorname{Prd}}-\sum \mathrm{MR}_{\operatorname{Exp}}\right)}\right] \\
x^{2} & =\frac{\left.\mathrm{MR}_{\operatorname{Exp}}-\mathrm{MR}_{\operatorname{Prd}}\right)^{2}}{\mathrm{~N}-n} \longrightarrow(12) \\
\mathrm{RMSE} & =\left[\frac{\sum\left(\mathrm{MR}_{\operatorname{Prd}}-\sum \mathrm{MR}_{\operatorname{Exp}}\right)^{2}}{\mathrm{~N}}\right]^{1 / 2} \longrightarrow(13) \\
\% \mathrm{E} & =\frac{100}{\mathrm{~N}} \sum \frac{\mathrm{MR}_{\operatorname{Exp}}-\mathrm{MR}_{\operatorname{Prd}}}{\mathrm{MR}_{\operatorname{Exp}}} \longrightarrow(14)
\end{aligned}
$$

\section{Calculation of the effective moisture diffusivity:-}

Effective moisture diffusivity $\left(\mathrm{D}_{\text {eff }}\right)$ is usually used to describe the drying characteristics of foodstuffs. Assuming that the sliced apricots samples were taking slab shape, Fick's second diffusion equation can be used to 
determine the effective moisture diffusivity of the apricots. Fick's diffusion equation for particles with a slab geometry is defined by the following equation (Crank, 1975):

$$
\mathrm{MR}=\frac{\mathrm{Mt}}{\mathrm{Mo}}=\frac{8}{\pi^{2}} \exp \left[\frac{\pi^{2} \mathrm{D}_{\text {eff }} \mathrm{t}}{4 \mathrm{~L}^{2}}\right] \longrightarrow(16)
$$

Taking the natural logarithm of both sides of Eq. (16) the following equation was obtained:

$$
\operatorname{Ln}(\mathrm{MR})=\operatorname{Ln}\left[\frac{8}{\pi^{2}}\right]-\left[\frac{\pi^{2}}{4 \mathrm{~L}^{2}} \mathrm{D}_{\text {eff }} \mathrm{t}\right] \longrightarrow \text { (17) }
$$

Diffusivities are typically determined by plotting experimental drying data in terms of ln MR versus drying time $t$ in Eq. (17), because the plot gives a straight line with a slope as follows (Zhengfu et al. 2007):

Slope $=\mathrm{K}=\frac{\pi^{2} \mathrm{D}_{\text {eff }}}{4 \mathrm{~L}^{2}} \longrightarrow$ (18)

Eq. (17) is estimated arithmetically by putting $D_{\text {eff }} t / 4 L^{2}=F_{0}$ (Fourier number for diffusion):

$$
\operatorname{Ln}(\mathrm{MR})=\operatorname{Ln}\left[\frac{8}{\pi^{2}}\right]-\left[\pi^{2} \mathrm{~F}_{0}\right] \longrightarrow(19)
$$

$=-0: 0212-0: 0101424 \operatorname{Ln}(\mathrm{MR})$

Then $\left(\mathrm{D}_{\text {eff }}\right)$ was determined from the following equation:

$$
\mathrm{D}_{\text {eff }}=\frac{\mathrm{F}_{0} \mathrm{~L}^{2}}{\mathrm{~T}} \longrightarrow
$$

\section{Calculation of the activation energy:-}

Activation energy (Ea) is the comparative easiness with which water molecules overcome the energy obstacle during their transfer through the samples The reliance of the effective moisture diffusivity on the temperature can be described by an Arrhenius-type equation (Akgun and Doymaz, 2005; Sanjuan et al., 2003) as follows:

$$
D_{\text {eff }}=\text { Do exp }\left[-\frac{E a}{\mathrm{RT}_{\mathrm{abs}}}\right]
$$

Taking natural logarithm of both sides of Eq. (22) it could be written as follows:

$$
\text { Ln } D_{\text {eff }}=\operatorname{Ln}\left(\text { Do) } \quad-\frac{E a}{R} \quad \frac{1}{T_{\text {abs }}} \longrightarrow\right.
$$


In order to obtain the values of the activation energy (Ea), the values of Ln (Deff) were plotted versus the reciprocal of the absolute temperature (1/Tabs) and the slope of the fitted straight line is equal to ( $\mathrm{Ea} / \mathrm{R})$. Linear regression analyses were used to fit the equation to the experimental data to obtain the coefficient of determination $\left(\mathrm{R}^{2}\right)$.

\section{Mathematical modeling of solar collector \& dryer.}

\section{1-Solar collector thermal performance:-}

Thermal performance of solar collector was evaluated by dividing Quantity of heat which is converted by the absorber to the collector area and calculated by the following equation.

$$
\mathrm{Q}_{\text {conv. }}=\mathrm{m} \mathrm{Cp}\left(\mathrm{T}_{\mathrm{c} \text { out }}-\mathrm{T}_{\mathrm{c} \text { in }}\right) / \mathrm{Ac}
$$

\section{2-Dryer thermal performance:-}

Thermal performance of dryer was evaluated by Quantity of heat gained by dryer and calculated as.

$$
\text { Qgain.I }_{\text {I }} \text { m Cp }\left(\mathrm{T}_{\mathrm{I}} \text { in }-\mathrm{T}_{\mathrm{I}} \text { out }\right)
$$

3- The thermal collector efficiency $\left(\% \eta_{\mathbf{C}}\right)$ :- collector efficiency is defined as the ratio of energy output of the collector to energy input (R.Ac) to the collector ( $\mathrm{J}$ ) and is calculated from the following mathematical formula.

$$
\%_{\eta_{\mathrm{C}}}=\frac{\mathrm{m} \cdot \mathrm{Cp} \cdot \Delta \mathrm{T}}{\operatorname{Rad} \cdot \mathrm{Ac}} \times 100 \longrightarrow(26)
$$

4- The thermal dryer efficiency $\left(\% \eta_{\mathbf{d}}\right)$ : - is useful for evaluating the actual evaporation of moisture from the food inside the drying chamber It is a direct measure of how efficiently the capacity of the (heated) air to absorb moisture is utilized. This is expressed as the ratio of energy used to evaporate water in the product $(\mathrm{Eu})$ to the energy provide to the air during drying (Ea) plus energy of the fan (EF) in the following form:

$$
\% \eta_{d} \frac{E_{u}}{E_{A}+E_{F}}=\times 100 \longrightarrow
$$

The heat used to evaporate water in the product $(\mathrm{Eu})$ is defined as: 


$$
\mathrm{E}_{\mathrm{u}}=\mathrm{m}_{\mathrm{e}} * \mathrm{~L}_{\mathrm{e}} \longrightarrow(28)
$$

The useful heat passed to the air $(\mathrm{EF})$ is defined as:

$$
\mathrm{E}_{\mathrm{A}}=m a * C p * \Delta T \longrightarrow(29)
$$

5-Collector effectiveness (EC\%):- Collector effectiveness in the following form:

$$
\mathrm{EC} \%=\frac{\left(\mathrm{T}_{\text {I in }}-\mathrm{T}_{\text {I out }}\right)}{\left(\mathrm{Tc}_{\text {out }}-\mathrm{T}_{\text {I in }}\right)} \times 100 \longrightarrow(30)
$$

6-Dryer effectiveness $\left(\boldsymbol{\%} \mathbf{E}_{\mathbf{I}}\right)$ :- Dryer effectiveness was simplified as per the following relationship.

$$
\% \mathrm{E}_{\mathrm{I}}=\frac{\left(\mathrm{Tc}_{\text {in }}-\mathrm{T}_{\mathrm{amb}}\right)}{\left(\mathrm{Tc}_{\text {out }}-\mathrm{T}_{\mathrm{amb}}\right)} \times 100
$$

7-Rehydration ratio and coefficient of rehydration: The rehydration ratio was estimated by placing $10 \mathrm{~g}$ of samples with $1000 \mathrm{ml}$ of boiling water about 5 minutes (Maskan ,2001).

$$
\begin{aligned}
\mathrm{Rr} & =\frac{\mathrm{W}_{\mathrm{r}}}{\mathrm{W}_{\mathrm{d}}} \longrightarrow \\
\mathrm{COR} & =\frac{\mathrm{W}_{\mathrm{r}}\left(100-\mathrm{M}_{\mathrm{i}}\right)}{\mathrm{W}_{\mathrm{d}}\left(100-\mathrm{M}_{\mathrm{f}}\right)} \longrightarrow
\end{aligned}
$$

\section{Measuring Instruments Data.}

"Weather station model PC-200. Was used for monitoring solar radiation $\left(1 \sim 2000 \mathrm{~W} / \mathrm{m}^{2}\right)$ with accuracy of $\pm 5 \%$.

Digital thermometer Model (TPM -10) series hand held Instrument. With a thermocouple was used for monitoring temperature with accuracy of \pm 1 ${ }^{\circ} \mathrm{C}$ and at range $\left(-50{ }^{\circ} \mathrm{C} \sim 110^{\circ} \mathrm{C}\right)$ by reading liquid crystal display (LCD) and operating in environment Humidity: range 5\% 80\%.

Digital Anemometer Model (GM816) series hand held Instrument. Used for measuring wind speed $\&$ temperature by reading liquid crystal display. Wind speed range $(0 \sim 30 \mathrm{~m} / \mathrm{s})$ while wind temperature range $(-10$ $\sim 45{ }^{\circ} \mathrm{C}$ ) with accuracy of $\pm 5 \%$ and $\pm 2 \%$ respectively.

Digital hygrometer-thermometer Model (ETI 810-155) series hand held Instrument. With a thermocouple was used for monitoring relative humidity at range $(20-99 \%)$ with accuracy of $\pm 5 \%$ and temperature at range: $-0{ }^{\circ} \mathrm{C}$ to $+49{ }^{\circ} \mathrm{C}$ in $--49{ }^{\circ} \mathrm{C}$ to $+69^{\circ} \mathrm{C}$ out. 
Electronic balance Model (SF-400) having an accuracy of $0.01 \mathrm{~g}$ with capacity $7 \mathrm{~kg}$ and the weight of samples were recorded on a LCD display.

\section{Drying experiments:-}

Experimental studies based on temperature and humidity measurements were performed on the dryer. Data were tested to find the most suitable model among five different models defining drying process set by a number of authors (Table 1). The different constants in the tested models were determined using non-linear regression procedure using IBM SPSS software package version 23 and MS Excel. Efficiency and effectiveness of collector and dryer under various air mass flow rate then comparison between the efficiency and effectiveness of collector and dryer for pointing to the best air mass flow rate.

Cost was calculated according to the following model:- Based on the climatic conditions in Aswan City which allow using the dryer almost all the year days (365 days). The costs and the main economic parameters based on the economic situation in Egypt are shown in table (2).

\section{Table (2)Payback period of the solar apricots dryer.}

\begin{tabular}{|l|c|}
\hline Cost of Cost of dryer & $1500 \mathrm{~L} . \mathrm{E}$ \\
Capacity of dryer & $6 \mathrm{~kg}$ \\
Depreciation & $300 \mathrm{L.E}$ \\
Life of dryer & $25 \mathrm{years}$ \\
Cost of maintenance & $1000 \mathrm{L.E}$ \\
Labor cost $10 \times 365$ year & 3650 L.E \\
Cost of electrical consumption, L.E /year & $77.76 \mathrm{L.E}$ \\
Cost of raw aproicts $15 \times 6 \times 365$ & 32850 L.E \\
\hline Total cost & $39377.76 \mathrm{~L} . \mathrm{E}$ \\
\hline Total income $100 \times 1.32 \times 365$ & $48180 \mathrm{~L} . \mathrm{E}$ \\
\hline Net income & $\mathbf{8 8 0 2 . 2 4 L . E}$ \\
\hline Note 1 US Dollar $\approx 18 \mathrm{L.E}$. & \\
\hline
\end{tabular}

Using this data, the payback period was calculated using the formula below (Neufville, 1990)

Payback period $=\frac{\text { Initial Investment }}{\text { Annual Net Undiscounted Benefits }}$

The payback period is determined as the time required for the investment cost to equal the return. 


\section{RESULTS AND DISSCUASION}

\section{Experimental run for solar-electrical dryer without load.}

Experiments extened to for three dayes in mide summer season (4,5 and 6 May, 2018)to test the experimental run for our electrical dryer. Designing and evaluation a thermal behavior of the solar collector \& dryer device requirmentes knowledge an important parameter such as adata on the ambient air temperature, air Speed, humidity of ambient Air and solar radiation. The outlet air temperature which inlet the dryer is animportant variable for drying operation; of the flat plate collector, it go up and down in the same direction as the solar radiation on this collector and increased by decreasing drying air velocity (Figs. 2-4).

The obtained data of the experiments indicated that during the peak afternoon hours an average rise of air temperature between the input and output of the collector was equal maximum to $12.8,15.9$ and $13.8{ }^{\circ} \mathrm{C}$ while it varying between $\left(6.2 \sim 17.4{ }^{\circ} \mathrm{C}\right),\left(5.2 \sim 17.8{ }^{\circ} \mathrm{C}\right)$ and $\left(4.6 \sim 16.9{ }^{\circ} \mathrm{C}\right)$ with an average air velocity of $1.5,2.2$ and $3 \mathrm{~m} / \mathrm{s}$ respectively. It is observed that the outlet air temperature of the solar collector increased to about $70^{\circ} \mathrm{c}$ and the losses of the solar collector outlet air arrive to 30.30 , 28.5 and $22.32 \%$ until they reached to the dryer for air speed 1.5,2.2 and $3 \mathrm{~m} / \mathrm{s}$ as they decreased by increased air velocity.

\section{Collector efficiency (\%ฤ):-}

Collector efficiency is shown in Fig.(5). The daily collector efficiencies at mass flow rate $0.0314 \mathrm{~kg} / \mathrm{s}$ ranged between 13.28 and $36.55 \%$, and at $0.0461 \mathrm{~kg} / \mathrm{s}$ ranged from 15.82 to $48.28 \%$ while at $0.0628 \mathrm{~kg} / \mathrm{s}$ were 37.83 to $64.49 \%$ respectively. So the collector efficiency at air mass flow rate $0.0628 \mathrm{~kg} / \mathrm{s}$ is better comparatively with other flow rates. Collector efficiency was increased with solar radiation increase until a limit where the efficiency tends to come down beyond this value. because the linear relationship between the velocity of air masse flow rate and the passage of local time,it observed that collector efficiency increases, rapidly at hight velocities $3 \mathrm{~m} / \mathrm{s}$ and nearly constant above this value.(Kutscher et al. 1993).noted that efficiency is nearly constant for approach velocities greater than $5 \mathrm{~m} / \mathrm{s}$. Our results are generally in agreement with earlier studies. 


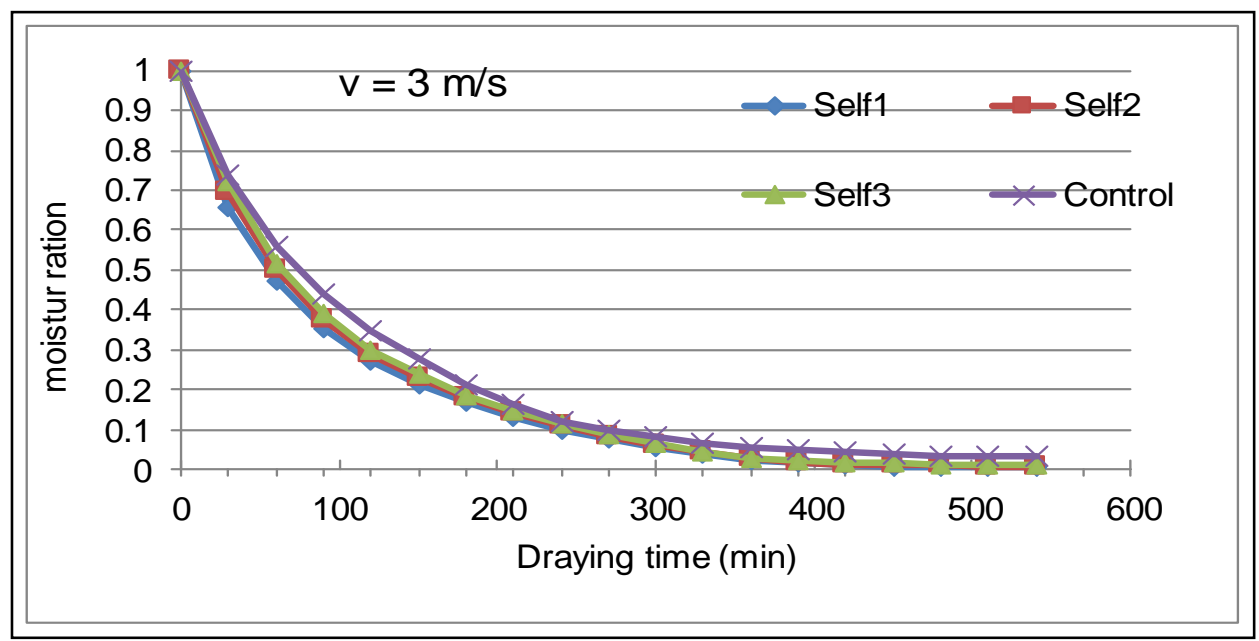

Fig. (2): Solar radiation and temperature variation of different elements of the collector on 4, May 2018.

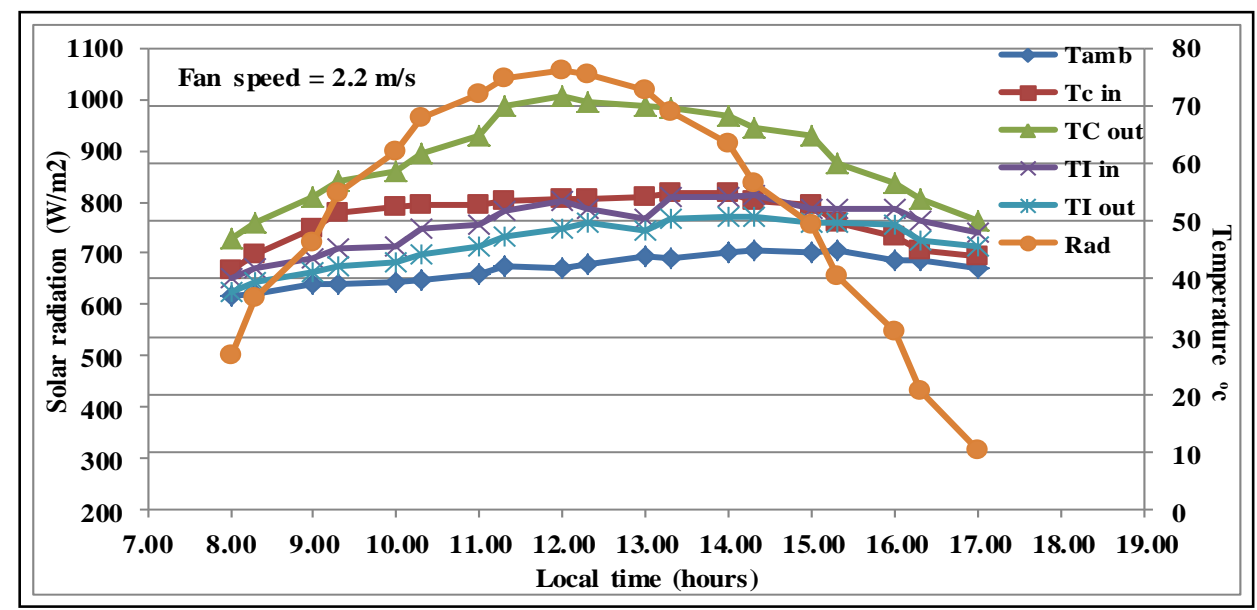

Fig. (3): Solar radiation and temperature variation of different elements of the collector on 5, May 2018.

Collector effectiveness (EC\%):-

Figure (6). Pointing to the thermal collector effectiveness .The maximum and the minimum of collector effectiveness were ranged from $7.24 \%$ to $64.79 \%$ and from $18.69 \%$ to 68.58 while it was $22.11 \%$ to $56.80 \%$ at air speed 1.5, 2.2 and $3 \mathrm{~m} / \mathrm{s}$ respectively. Solar collector effectiveness at different solar time starting 8.00 am to $5.00 \mathrm{pm}$ depend on the rise in air temperature between inlet and outlet $(\Delta \mathrm{T})$ starts small in the morning and gradually increases until it reached maximum at one P.M. then decreased 
gradually until sunset. The average effectiveness for collector ranged from $16 \%$ to $64 \%$.and it was bitter at fan speed $2 \mathrm{~m} / \mathrm{s}$ compering with the others velocities.

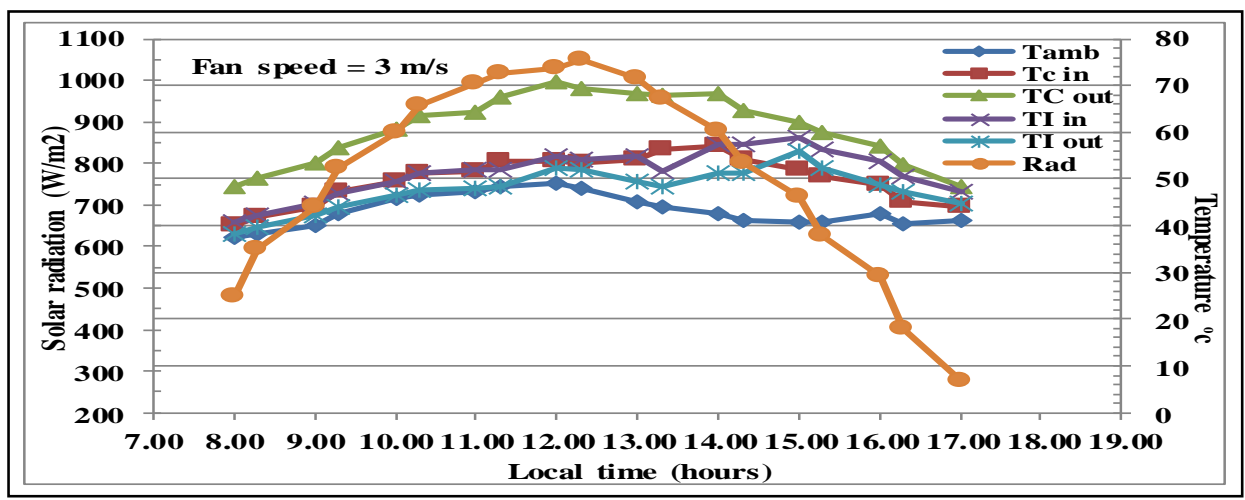

Fig. (4): Solar radiation and temperature variation of different elements of the collector on 6,May 2018.

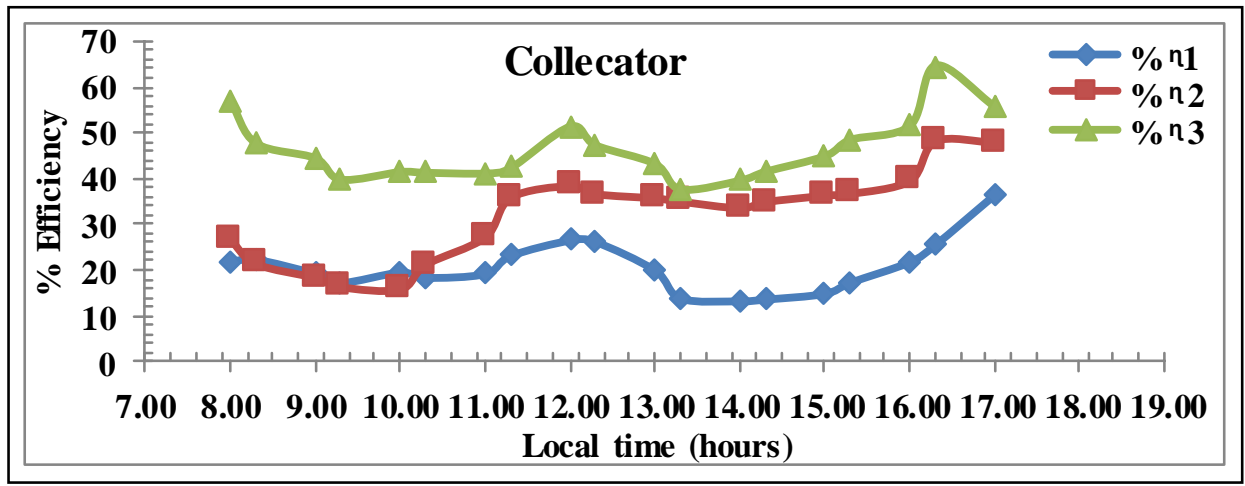

Fig. (5): Daily collector efficiency and local time.

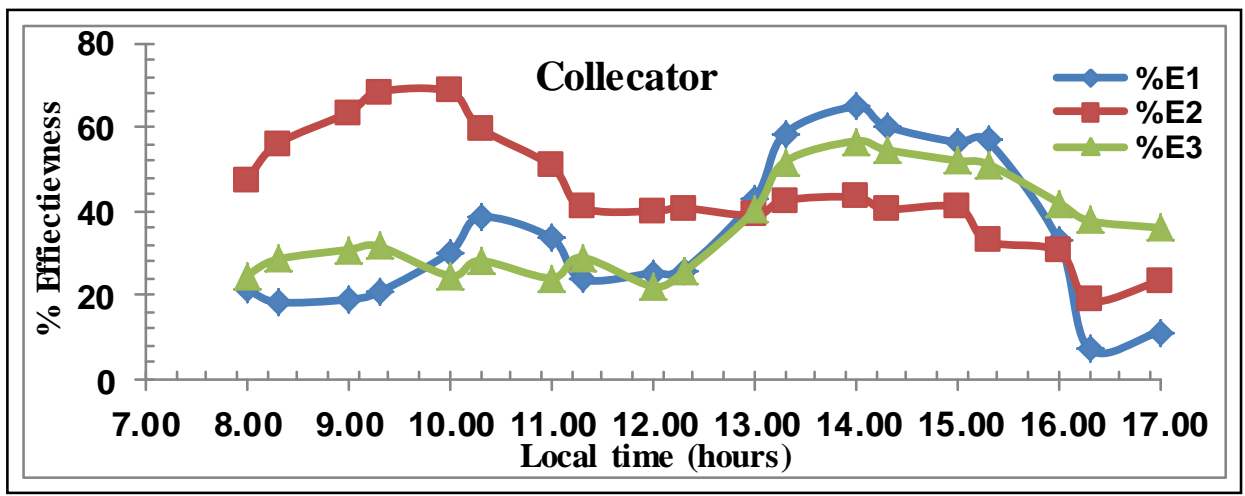

Fig. (6): Daily collector effectiveness and local time. 
Dryer efficiency (\%)): - The daily dryer efficiency is given in Fig. (7) and it ranged from (3.11\% to $32.86 \%),(2.16 \%$ to $37.17 \%)$ and $(1.95 \%$ to $23.44 \%$ ) at air speed 1.5, 2.2 and $3 \mathrm{~m} / \mathrm{s}$ respectively.

The system efficiency depends also on the type of dryer, product dried and final moisture content. The comprehensive efficiency of drying is generally in the range of 20-30\% for forced convection dryers (Purohit et al., 2006).It observed the system dryer efficiency for air speed $1.5 \mathrm{~m} / \mathrm{s}$ higher comparatively to other velocities. There is a seasonal variation in the climatic parameters of ambient air and the solar radiation so that the efficiency of is not uniform and are often ranged from 2 to $37 \%$. The thermal efficiency is higher on the first hours of drying because the presence of moisture near to the surface of the product; then decreased continuously until the end of drying because the moisture content of the product is also decreased; so that it required more energy to drive out the same amount of moisture from the product.

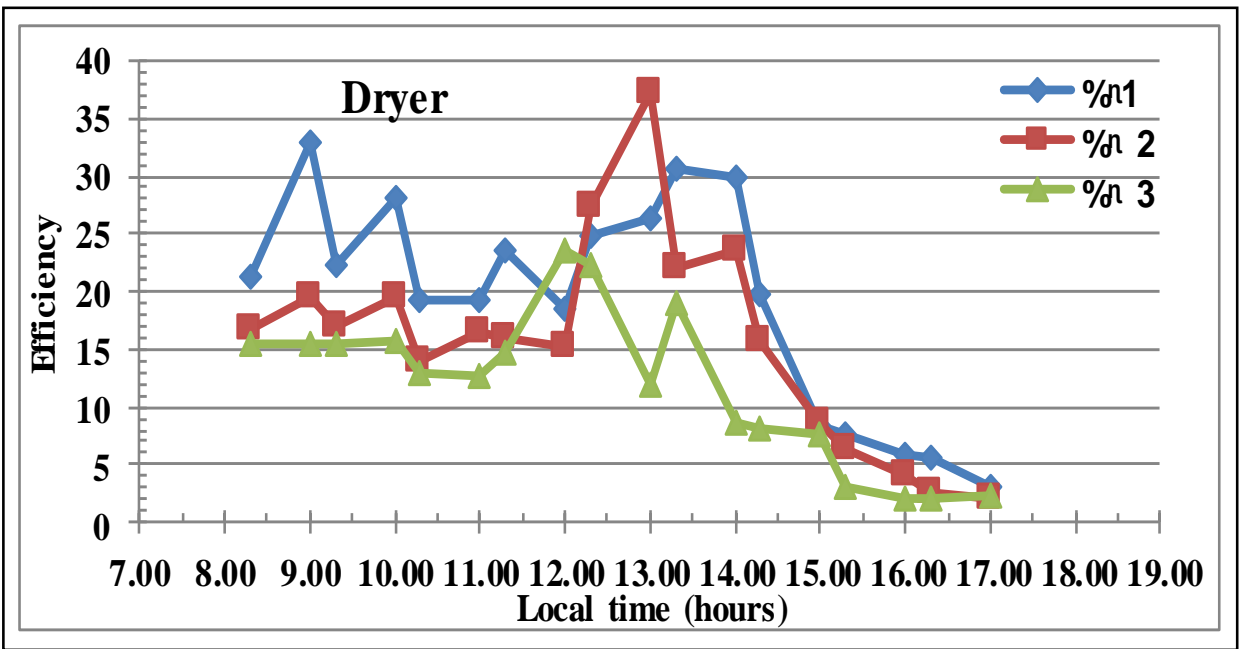

Fig. (7): Daily collector efficiency versus flow rates and local time.

Dryer effectiveness (Ed\%):- Fig.(8) shed light on the effectiveness of the dryer which are ranged from $21.53 \%$ to $36.22 \%, 8.79 \%$ to $5.81 \%$ and 13.37 to $62.16 \%$ for air Speed rates $1.5,2.2$ and $3 \mathrm{~m} / \mathrm{s}$ respectively. It observed that the effectiveness of air speed $1.5 \mathrm{~m} / \mathrm{s}$ is the optimum almost the time. 


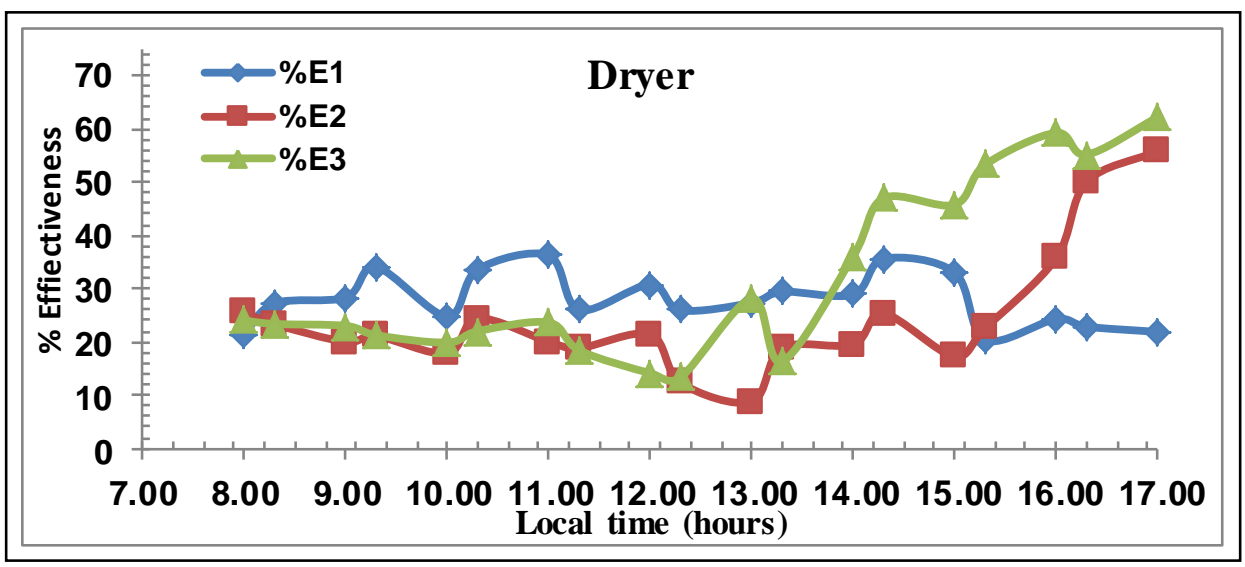

Fig. (8): Daily dryer effectiveness versus flow rates and local time.

\section{Effect of shelf position on drying time}

Fig. 9-10 present relation between moisture ratio and drying time at air speed rates 1.5, 2.2 and $3 \mathrm{~m} / \mathrm{s}$ for three position of shelf in the dryer and control respectively. We observed in the three cases that the constant ratedrying period was not detected in drying curves. The moisture ration differed with the position of the shelves in the dryer. This difference can be explained by a gradual saturation of the air as it passes over the first shelves consequence of non-homogeneity of the product at the end of drying. Moisture ration decreased with increased air fan speed and the position of shelf in the dryer. The higher hot air temperature led to the faster drying rate and the shorter drying time. As the drying air temperature raises, the transfer rate of moisture from the internal of the drying apricots to its surface and the vaporization potential of moisture at the surface increased, resulting in the higher drying rate.so that decreased air temperature from the first shelf to another reduces the ability to carry the same moisture quantity equally.

Figs. (9) Show the evolution-drying rate under moisture ration in three air speed rates in three shelf's position. The constant rate period was not observed in the first. Drying rate increased with the increase of air-drying temperature and speed. So that drying rate increases various with drying time by increased air speed and shelf's position.

\section{Suitable model for describing drying process:-}

All approximate models were calculated using SPSS and MS Excel The best is the one which has a maximum $\mathrm{R}^{2}$ and a minimum $\mathrm{x}^{2}$. 

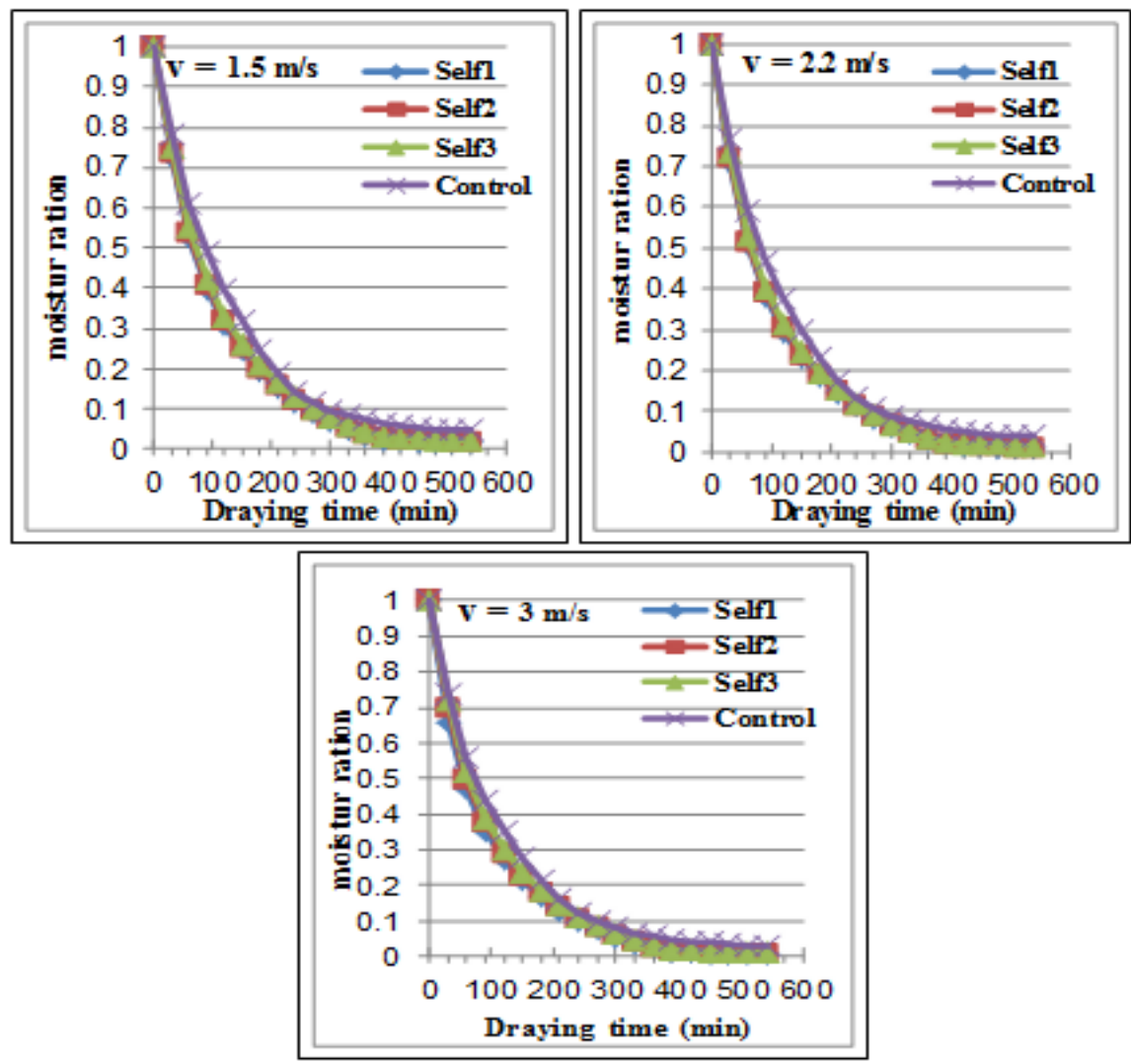

Fig. (9): Effect of shelf-position on apricots drying of versus time at speed 1.5, 2.2 and $3 \mathrm{~m} / \mathrm{s}$.

The data of the moisture content of the product obtained at various temperatures and speed of the air drying, for apricots were converted into report/ratio of moisture (MR) and then adapted to 5 mathematical models of drying. It is observed that, the highest value of $\mathrm{R}^{2}$ and the lowest value of $\mathrm{x}^{2}$ were obtained starting from the model of Page, Modified page and Modified page, as displayed in table (3-5). Consequently, this model was selected as a suitable model to represent the behavior of this variety of apricots in this condition.

Payback analysis: - The payback period is calculated as the time required for the investment cost to equal the return. In our case the payback period is very small (1.34 years) compared to the life of the dryer (25 years), so the dryer will dry product free of cost for almost its entire life period.

$$
\text { Payback period }=\frac{48180}{39377.76}=1.22 \text { years. }
$$




\section{Rehydration Characteristics:-}

The rehydration ratio of dried apricots is presented in table 6. The rehydration ratio and coefficient of rehydration were calculated to return to the base block of the dried apricots. Higher rehydration ratio indicates better product. The rehydration ratio ranged from 2.90 to 2.20 at different parameters. The three varieties of the dried apricots were having greater rehydration ratio at air speed $3 \mathrm{~m} / \mathrm{s}$ compared with the sample dried at higher rates. At lower air speed and high Temperature plant cells are less vandalized, so that the material is capable of more absorption of water. It was noted that as the air speed decreased there is no great difference in the rehydration ratio and coefficient of rehydration with different parameters.
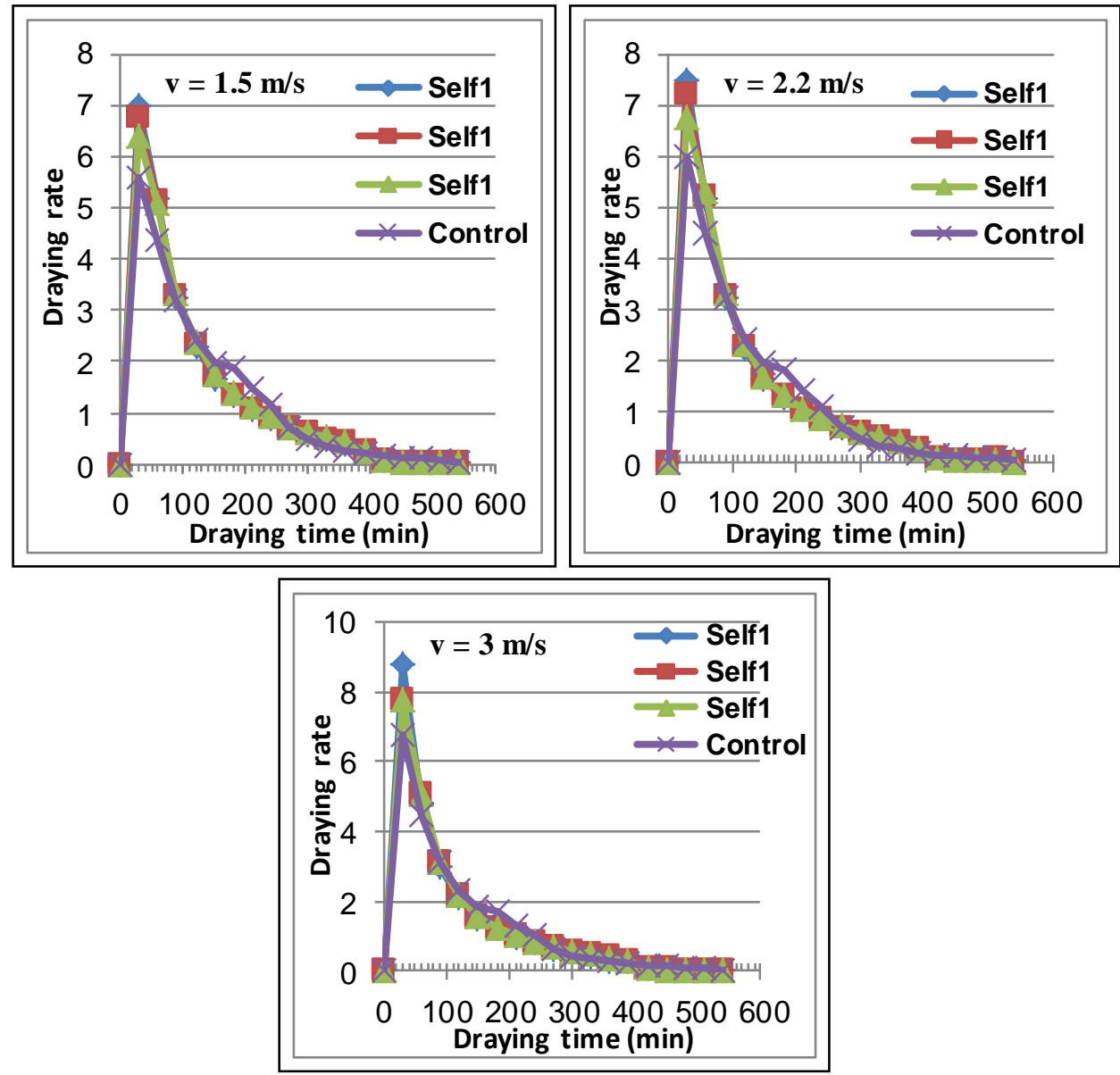

Fig. (10): Effect of drying rate for apricots on versus time at speed 1.5, 2.2 and $3 \mathrm{~m} / \mathrm{s}$. 
Table (3) Statistical results obtained for the thin layer drying models for apricots at $1.5 \mathrm{~m} / \mathrm{s}$.

\begin{tabular}{|c|c|c|c|c|c|c|c|c|c|}
\hline \multirow{2}{*}{$\frac{\bar{d}}{\frac{0}{0}}$} & \multirow{2}{*}{ 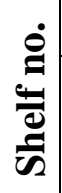 } & \multicolumn{3}{|c|}{ Constants } & \multicolumn{5}{|c|}{ Determination Statistical Coefficient } \\
\hline & & $\mathbf{K}$ & $\mathbf{n}$ & $\mathbf{A}$ & $\mathbf{R}^{2}$ & $\mathbf{X}^{2}$ & MBE & RMS & $\mathbf{E \%}$ \\
\hline \multirow{4}{*}{ 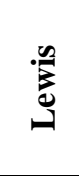 } & $\mathbf{S}_{\mathbf{1}}$ & -0.008296 & - & - & 0.984000 & 0.001379 & $\mathbf{0 . 0 2 6 1 6 7}$ & $\mathbf{0 . 0 3 6 0 8 5}$ & -0.649676988 \\
\hline & $\mathbf{S}_{\mathbf{2}}$ & -0.007880 & - & - & $\mathbf{0 . 9 8 0 3 0 0}$ & $\mathbf{0 . 0 0 1 8 1 5}$ & $\mathbf{0 . 0 3 1 4 8 3}$ & 0.041402 & -0.762341183 \\
\hline & $\mathbf{S}_{\mathbf{3}}$ & -0.007499 & - & - & 0.976400 & 0.002091 & $\mathbf{0 . 0 3 4 9 3 8}$ & 0.044434 & -0.819032749 \\
\hline & $\mathbf{C}$ & -0.005954 & - & - & 0.958700 & 0.005013 & $\mathbf{0 . 0 5 7 9 3 6}$ & 0.291916 & -1.19084061 \\
\hline \multirow{4}{*}{ E } & $\mathbf{S}_{1}$ & 0.014633 & 0.914286 & - & 0.996100 & 0.000050 & -0.000161 & 0.006676 & 0.003991513 \\
\hline & $\mathbf{S}_{\mathbf{2}}$ & 0.014637 & 0.908213 & - & 0.995500 & 0.000047 & 0.000448 & 0.006478 & -0.010849291 \\
\hline & $\mathbf{S}_{\mathbf{3}}$ & $\mathbf{0 . 0 1 3 8 8 3}$ & 0.910846 & - & 0.994500 & 0.000058 & 0.001156 & 0.007195 & -0.027110396 \\
\hline & $\mathbf{C}$ & 0.012979 & 0.893800 & - & 0.987700 & 0.000313 & 0.003455 & 0.016674 & -0.071011408 \\
\hline \multirow{4}{*}{ 胥 } & $\mathbf{S}_{1}$ & $\mathbf{0 . 0 0 9 8 4 7}$ & 0.914286 & - & 0.996100 & 0.000050 & -0.000146 & 0.006674 & 0.003625501 \\
\hline & $\mathbf{S}_{\mathbf{2}}$ & 0.009551 & 0.908213 & - & 0.995500 & 0.000047 & 0.000434 & 0.006477 & -0.010510563 \\
\hline & $\mathbf{S}_{\mathbf{3}}$ & 0.009134 & 0.910846 & - & 0.994500 & 0.000058 & 0.001156 & 0.007195 & -0.027110396 \\
\hline & $\mathbf{C}$ & 0.007746 & $\mathbf{0 . 8 9 3 8 0 0}$ & - & 0.987700 & 0.000313 & 0.003468 & 0.016679 & -0.071279864 \\
\hline \multirow{4}{*}{ 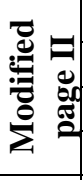 } & $\mathbf{S}_{\mathbf{1}}$ & 0.655668 & 0.914286 & - & 0.996100 & 0.000050 & -0.000145 & 0.006674 & 0.003591805 \\
\hline & $\mathbf{S}_{\mathbf{2}}$ & 0.639544 & 0.908213 & - & $\mathbf{0 . 9 9 5 5 0 0}$ & $\mathbf{0 . 0 0 0 0 4 7}$ & 0.000424 & 0.006476 & -0.010272945 \\
\hline & $\mathbf{S}_{\mathbf{3}}$ & 0.613239 & 0.910846 & - & 0.994500 & 0.000058 & 0.001157 & 0.007196 & -0.02711438 \\
\hline & $\mathbf{C}$ & 0.007746 & 0.893811 & - & 0.987700 & 0.000313 & 0.003468 & 0.016679 & -0.071289568 \\
\hline \multirow{4}{*}{ 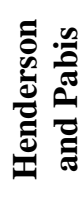 } & $\mathbf{S}_{1}$ & 0.008000 & - & 0.8513 & 0.984000 & $\mathbf{0 . 0 0 1 6 8 7}$ & -0.004424 & $\mathbf{0 . 0 3 8 7 2 7}$ & $\mathbf{0 . 1 0 9 8 4 3 9 5 4}$ \\
\hline & $\mathbf{S}_{\mathbf{2}}$ & 0.0.008 & - & 0.828900 & $\mathbf{0 . 9 8 0 3 0 0}$ & $\mathbf{0 . 0 0 2 3 3 5}$ & -0.015869 & 0.045560 & $\mathbf{0 . 3 8 4 2 5 9 3 0 4}$ \\
\hline & $\mathbf{S}_{3}$ & -0.007000 & - & $\mathbf{0 . 8 1 7 5 0 0}$ & 0.976400 & 0.002922 & -0.001651 & 0.050967 & 0.038699179 \\
\hline & $\mathbf{C}$ & -0.006000 & - & 0.763500 & 0.958700 & 0.005727 & -0.021216 & $\mathbf{0 . 0 7 1 3 5 1}$ & $\mathbf{0 . 4 3 6 0 8 3 1 7 1}$ \\
\hline
\end{tabular}

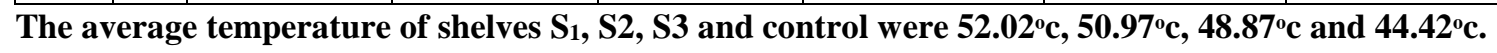


Table (4) Statistical results obtained for the thin layer drying models for apricots at $2.2 \mathrm{~m} / \mathrm{s}$.

\begin{tabular}{|c|c|c|c|c|c|c|c|c|c|}
\hline \multirow{2}{*}{$\frac{\bar{d}}{\dot{\theta}}$} & \multirow{2}{*}{ 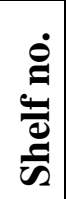 } & \multicolumn{3}{|c|}{ Constants } & \multicolumn{5}{|c|}{ Determination Statistical Coefficient } \\
\hline & & $\mathbf{K}$ & $\mathbf{n}$ & $\mathbf{a}$ & $\mathbf{R}^{2}$ & $\mathbf{X}^{2}$ & MBE & RMS & $\mathrm{E} \%$ \\
\hline \multirow{4}{*}{ 氛 } & $\mathbf{S}_{1}$ & -0.009315 & - & - & 0.990900 & 0.000622 & 0.013108 & 0.024230 & -0.340854305 \\
\hline & $\mathbf{S}_{2}$ & -0.008890 & - & - & 0.990700 & 0.000820 & 0.017761 & 0.027825 & -0.452009799 \\
\hline & $\mathbf{S}_{\mathbf{3}}$ & -0.008879 & - & - & 0.983300 & 0.001259 & 0.025159 & 0.034479 & -0.623142975 \\
\hline & $\mathrm{C}$ & -0.004619 & - & - & 0.958400 & 0.004558 & 0.054915 & 0.065607 & -1.183785387 \\
\hline \multirow{4}{*}{ ت્ષ } & $\mathbf{S}_{1}$ & 0.014301 & $\mathbf{0 . 9 3 0 5 7 5}$ & - & 0.995900 & 0.000094 & -0.001704 & 0.009152 & 0.041840005 \\
\hline & $\mathbf{S}_{\mathbf{2}}$ & 0.014213 & 0.926228 & - & 0.996800 & 0.000068 & -0.000955 & 0.007785 & 0.022945868 \\
\hline & $\mathbf{S}_{\mathbf{3}}$ & 0.013900 & $\mathbf{0 . 9 2 3 4 7 7}$ & - & 0.995800 & 0.000056 & 0.000230 & 0.007058 & -0.005701647 \\
\hline & $\mathrm{C}$ & 0.000294 & 1.364151 & - & 0.992700 & 0.147442 & 0.346991 & 0.362022 & -7.479969733 \\
\hline \multirow{4}{*}{ 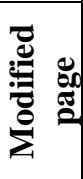 } & $\mathbf{S}_{1}$ & 0.010677 & 0.930575 & - & 0.995900 & 0.000094 & -0.001609 & 0.009152 & 0.041840005 \\
\hline & $\mathbf{S}_{2}$ & 0.010129 & 0.926228 & - & 0.996800 & 0.000068 & -0.000902 & 0.007785 & 0.022945868 \\
\hline & $\mathbf{S}_{\mathbf{3}}$ & 0.009753 & 0.923477 & - & 0.995800 & 0.000056 & 0.000230 & 0.007058 & -0.005701647 \\
\hline & $\mathbf{C}$ & 0.002575 & 1.364151 & - & 0.992700 & 0.147442 & 0.346991 & 0.362022 & -7.479969733 \\
\hline \multirow{4}{*}{ 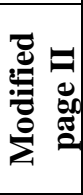 } & $\mathbf{S}_{1}$ & 0.685779 & 0.930575 & - & 0.995900 & 0.000094 & -0.001618 & 0.009154 & $\mathbf{0 . 0 4 2 0 6 8 7 5 3}$ \\
\hline & $\mathbf{S}_{\mathbf{2}}$ & 0.669315 & 0.926228 & - & 0.996800 & 0.000068 & -0.000906 & 0.007786 & 0.023064538 \\
\hline & $\mathbf{S}_{\mathbf{3}}$ & 0.647071 & 0.923477 & - & 0.995800 & 0.000055 & 0.000264 & 0.007017 & -0.006538246 \\
\hline & $\mathbf{C}$ & 0.085443 & 1.364151 & - & 0.992700 & 0.147452 & 0.347004 & 0.362034 & -7.480237628 \\
\hline \multirow{4}{*}{ 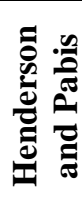 } & $\mathbf{S}_{1}$ & -0.009000 & - & 0.927200 & 0.990900 & 0.000507 & 0.002761 & 0.021236 & -0.071799362 \\
\hline & $\mathbf{S}_{\mathbf{2}}$ & -0.009000 & - & 0.898100 & 0.990700 & 0.000763 & -0.008687 & 0.026038 & $\mathbf{0 . 2 2 1 0 7 6 7 3 7}$ \\
\hline & $\mathbf{S}_{3}$ & -0.008000 & - & $\mathbf{0 . 8 5 3 5 0 0}$ & 0.983300 & 0.001707 & -0.004401 & 0.038958 & 0.109001607 \\
\hline & $\mathrm{C}$ & -0.006000 & - & 0.762100 & 0.965600 & 0.005521 & -0.009106 & 0.070055 & 0.196304084 \\
\hline
\end{tabular}

The average temperature of shelves $S_{1}, S_{2}, S_{3}$ and control were $49.48{ }^{\circ} \mathrm{c}, 48.08{ }^{\circ} \mathrm{c}, 48.08^{\circ} \mathrm{c}$ and $41.79^{\circ} \mathrm{c}$. 
Table (5) Statistical results obtained for the thin layer drying models for apricots at $3 \mathrm{~m} / \mathrm{s}$.

\begin{tabular}{|c|c|c|c|c|c|c|c|c|c|}
\hline \multirow{2}{*}{$\frac{\bar{d}}{\tilde{\delta}}$} & \multirow{2}{*}{ 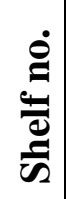 } & \multicolumn{3}{|c|}{ Model Constants } & \multicolumn{5}{|c|}{ Determination Statistical Coefficient } \\
\hline & & $\mathbf{K}$ & $\mathbf{n}$ & $\mathbf{A}$ & $\mathbf{R}^{2}$ & $\mathbf{X}^{2}$ & MBE & RMS & $\mathbf{E \%}$ \\
\hline \multirow{4}{*}{ 番 } & $\mathbf{S}_{1}$ & -0.010516 & - & - & 0.994500 & 0.000689 & -0.010207 & 0.025508 & -0.153427014 \\
\hline & $\mathbf{S}_{\mathbf{2}}$ & -0.009791 & - & - & 0.991000 & 0.000509 & 0.008128 & 0.021916 & -0.227947876 \\
\hline & $\mathbf{S}_{3}$ & -0.004619 & - & - & 0.958400 & 0.000686 & 0.015820 & 0.025456 & -0.404273222 \\
\hline & $\mathbf{C}$ & -0.004619 & - & - & 0.958400 & 0.004803 & 0.055644 & 0.067352 & -1.270061727 \\
\hline \multirow{4}{*}{ E્ } & $S_{1}$ & 0.014163 & 0.953026 & - & 0.984900 & 0.000395 & -0.004729 & 0.018736 & 0.132282477 \\
\hline & $\mathbf{S}_{2}$ & 0.014590 & 0.931874 & - & 0.994700 & 0.000139 & -0.002395 & 0.011131 & 0.096577265 \\
\hline & $\mathbf{S}_{\mathbf{3}}$ & 0.013730 & 0.934004 & - & 0.996200 & 0.000074 & -0.000963 & 0.008112 & 0.023242257 \\
\hline & $\mathbf{C}$ & 0.016989 & 0.865554 & - & 0.993200 & 0.000125 & 0.001765 & 0.010522 & -0.040288532 \\
\hline \multirow{4}{*}{ 胥 } & $S_{1}$ & 0.011546 & 0.918969 & - & 0.984900 & 0.000395 & -0.003465 & 0.018736 & $\begin{array}{c}0.076396578 \\
\end{array}$ \\
\hline & $\mathbf{S}_{2}$ & 0.010711 & 0.931874 & - & 0.994700 & 0.000139 & -0.002535 & 0.011131 & 0.063495763 \\
\hline & $\mathbf{S}_{3}$ & 0.010141 & 0.934004 & - & 0.996200 & 0.000074 & -0.000910 & 0.008112 & 0.023242257 \\
\hline & $\mathbf{C}$ & 0.009021 & 0.865554 & - & 0.993200 & 0.000125 & 0.001765 & 0.010522 & -0.040288532 \\
\hline \multirow{4}{*}{ 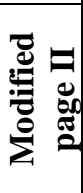 } & $S_{1}$ & 0.757221 & 0.953026 & - & 0.991500 & 0.000442 & -0.008035 & 0.019811 & 0.204228949 \\
\hline & $\mathbf{S}_{2}$ & 0.703350 & 0.931874 & - & 0.994700 & 0.000139 & -0.002385 & 0.011128 & 0.063233145 \\
\hline & $\mathbf{S}_{\mathbf{3}}$ & 0.667778 & 0.934004 & - & 0.996200 & 0.000074 & -0.000907 & 0.008112 & 0.023166999 \\
\hline & $\mathbf{C}$ & 0.621574 & 0.865554 & - & $\mathbf{0 . 9 9 3 2 0 0}$ & 0.000125 & 0.001774 & 0.010525 & -0.040481572 \\
\hline \multirow{4}{*}{ 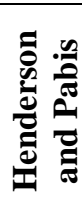 } & $S_{1}$ & -0.011000 & - & 1.011900 & 0.994500 & 0.000730 & 0.000301 & 0.025475 & -0.028965396 \\
\hline & $\mathbf{S}_{2}$ & -0.010000 & - & 0.964700 & 0.992400 & 0.000298 & -0.003422 & 0.016280 & 0.090738832 \\
\hline & $\mathbf{S}_{\mathbf{3}}$ & -0.009000 & - & 0.905500 & 0.988700 & 0.000664 & -0.006055 & 0.024304 & 0.15473891 \\
\hline & $\mathbf{C}$ & -0.007000 & - & 0.749900 & 0.970300 & 0.005481 & -0.027524 & 0.069797 & 0.628222791 \\
\hline
\end{tabular}

The average temperature of shelves $S_{1}, S_{2}, S_{3}$ and control were $51.35,48.81,47.85$ and $43.25^{\circ} \mathrm{c}$. 
Table (6):-Rehydration Characteristics of apricots at various air speed rates.

\begin{tabular}{|c|c|c|c|c|}
\hline Air speed & Shelf No. & Average Temperature & $\mathbf{R R}$ & COR \\
\hline \multirow{3}{*}{$1.5 \mathrm{~m} / \mathrm{s}$} & $\mathbf{S}_{1}$ & 52.02 & 2.6 & 0.33407821 \\
\hline & $\mathbf{S}_{2}$ & 50.97 & 2.5 & 0.32951289 \\
\hline & $\mathbf{S}_{3}$ & 48.87 & 2.4 & 0.32566372 \\
\hline Control & $\mathbf{C}_{1}$ & 44.42 & 2.35 & 0.31207598 \\
\hline \multirow{3}{*}{$2.2 \mathrm{~m} / \mathrm{s}$} & $\mathbf{S}_{1}$ & 49.48 & 2.75 & 0.337153518 \\
\hline & $\mathbf{S}_{2}$ & 48.08 & 2.65 & 0.33125 \\
\hline & $\mathbf{S}_{3}$ & 46.37 & 2.61 & 0.335550587 \\
\hline Control & $\mathrm{C}_{2}$ & 41.79 & 2.2 & 0.343283582 \\
\hline \multirow{3}{*}{$3 \mathrm{~m} / \mathrm{s}$} & $\mathbf{S}_{1}$ & 51.35 & 2.9 & 0.343106996 \\
\hline & $\mathbf{S}_{2}$ & 48.81 & 2.8 & 0.338235294 \\
\hline & $\mathbf{S}_{\mathbf{3}}$ & 47.85 & 2.7 & $\mathbf{0 . 3 3 5 4 9 4 3 2 7}$ \\
\hline Control & $\mathrm{C}_{3}$ & 43.25 & 2.3 & 0.328571429 \\
\hline
\end{tabular}

\section{Effective moisture diffusivity (Deff):-}

Fick's second law can be used to describe the drying process of apricot due to the fact that the drying occurred mainly in the falling-rate period and liquid diffusion controlled the process. The determined values of effective moisture diffusion coefficient ( $\left.\mathrm{D}_{\mathrm{eff}}\right)$ for all the drying temperatures calculated are presented in Fig. 6, and the values of effective moisture diffusion coefficient are shown in Table 2. It can be observed that the $D_{\text {eff }}$ of apricot varied from $1.94708 \times 10^{-5}$ to $3.01943 \times 10^{-5} \mathrm{~m}^{2} / \mathrm{s}$ in the range of temperatures from 47.85 to $52.02{ }^{\circ} \mathrm{C}$, which suggests an increase of $D_{\text {eff }}$ with the air speed rate and drying temperature raised the greater the rate of moisture diffusion can be attributed to the increase of the vapor's pressure inside the samples, which would lead to the rapid movement of water at elevated drying temperatures (Shi et al., 2013).

\section{Computation of activation energy (Ea):-}

The activation energy (Ea) is a measure of the effect on the diffusion coefficient and can be obtained from experimental data of the effective diffusivity. Fig. (7) presents a plot of the value of $\ln \mathrm{D}$ versus $1 / \mathrm{Ta}$ for the air velocities of $1.5,2.2$ and $3 \mathrm{~m} / \mathrm{s}$. The diffusivity constant $\left(\mathrm{D}_{\mathrm{o}}\right)$ and activation energy (Ea) calculated from the linear regression Table (5). The values of the activation energy lie from 12.7 to $110 \mathrm{~kJ} / \mathrm{mol}$ for $\operatorname{most}$ food materials (Zogzas 1996). Ea value varied within 34.35 to $71.12 \mathrm{~kJ} / \mathrm{mol}$ for different air velocities with apricots. The variation of the activation energy values versus air velocities is plotted in Fig. 5. high values of Ea are related to the nature of materials where water is bounded more strongly to the structure and consequently more difficult to be removed. 
Ea values decreased with the increased of Air speed. The lower activation energy in case of drying indicates that drying of apricots requires less energy and is hence a cost and energy-saving method.
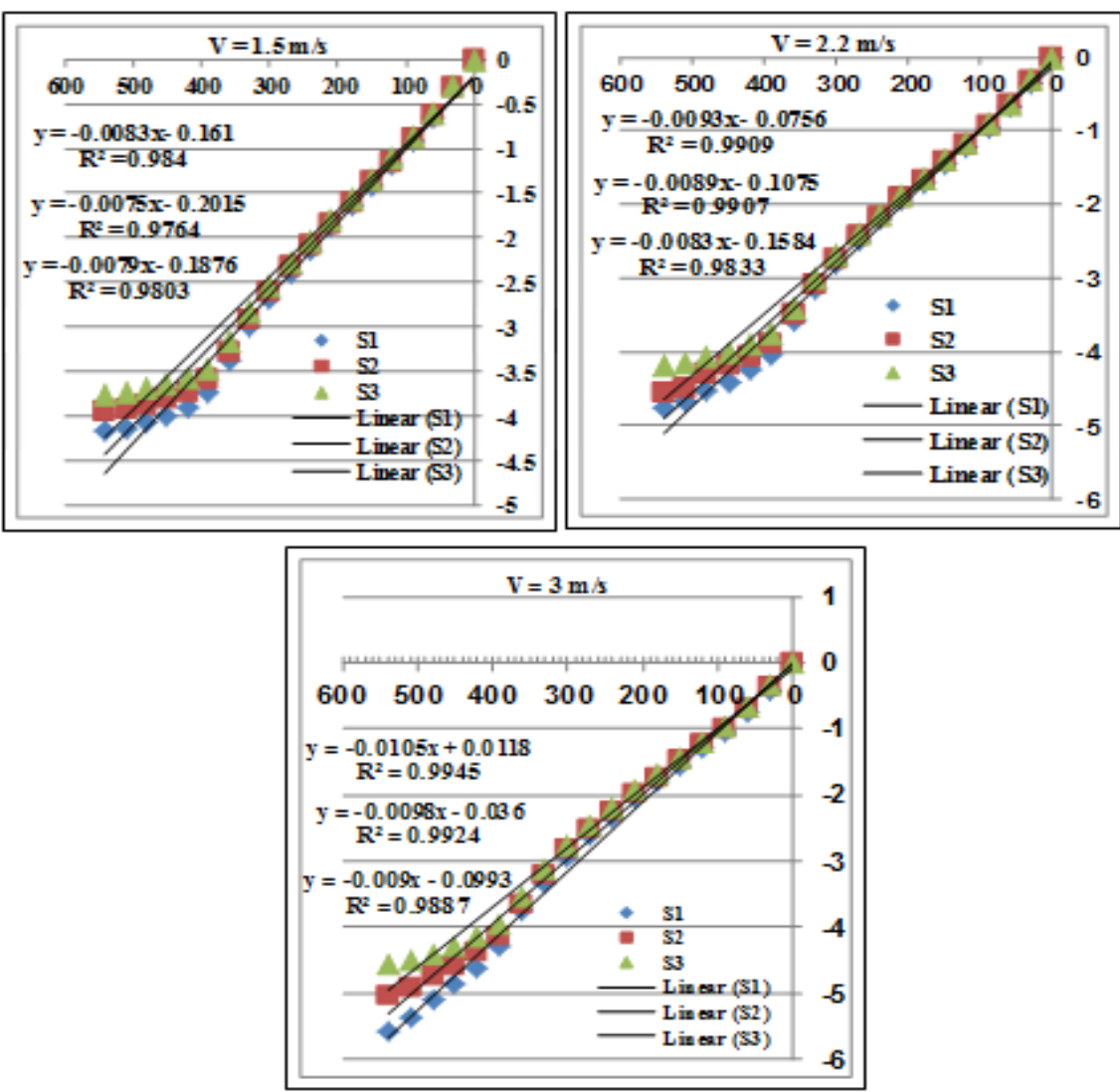

Fig. (6). Experimental logarithmic moisture ratio (MR) in function drying time at different drying temperatures for apricots.

Tabla (2).Diffusivity coefficient at various air speed rate and different temperature.

\begin{tabular}{|c|c|c|c|}
\hline Air speed & Shelf No. & Drying temp. ${ }^{\circ} \mathrm{C}$ & Diffusivity coefficient $\left(D_{\text {eff }}\right) \mathrm{m}^{2} / \mathrm{s}$ \\
\hline \multirow{3}{*}{$1.5 \mathrm{~m} / \mathrm{s}$} & $\mathbf{S}_{1}$ & 52.02 & $2.15182 \times 10^{-5}$ \\
\hline & $\mathbf{S}_{2}$ & 50.97 & $2.04607 \times 10^{-5}$ \\
\hline & $\mathbf{S}_{3}$ & 48.87 & $1.94708 \times 10^{-5}$ \\
\hline \multirow{3}{*}{$2.2 \mathrm{~m} / \mathrm{s}$} & $\mathbf{S}_{1}$ & 49.48 & $2.41850 \times 10^{-5}$ \\
\hline & $\mathbf{S}_{2}$ & 48.08 & $2.30545 \times 10^{-5}$ \\
\hline & $\mathbf{S}_{3}$ & 46.37 & $2.15878 \times 10^{-5}$ \\
\hline \multirow{3}{*}{$3 \mathrm{~m} / \mathrm{s}$} & $\mathbf{S}_{1}$ & 51.35 & $3.01943 \times 10^{-5}$ \\
\hline & $\mathbf{S}_{2}$ & 48.81 & $2.53304 \times 10^{-5}$ \\
\hline & $\mathbf{S}_{3}$ & 47.85 & $2.33896 \times 10^{-5}$ \\
\hline
\end{tabular}


Table (4) Effective diffusivity and activation energy at various air speed rate.

\begin{tabular}{|c|c|c|c|}
\hline \multicolumn{4}{|c|}{ Deef $=D_{O} \operatorname{EXP}(-3.13 / T+273.15)$} \\
\hline Air speed & Shelf No. & $\mathrm{D}_{\mathrm{O}}$ & Ea $(\mathrm{kJ} / \mathrm{mol} \mathrm{K})$ \\
\hline \multirow{3}{*}{$1.5 \mathrm{~m} / \mathrm{s}$} & $\mathbf{S}_{1}$ & $2.57 \times 10^{-4}$ & \multirow{3}{*}{34.35} \\
\hline & $\mathbf{S}_{2}$ & $2.39 \times 10^{-4}$ & \\
\hline & $\mathbf{S}_{3}$ & $2.32 \times 10^{-4}$ & \\
\hline \multirow{3}{*}{$2.2 \mathrm{~m} / \mathrm{s}$} & $\mathbf{S}_{1}$ & $2.75 \times 10^{-4}$ & \multirow{3}{*}{36.38} \\
\hline & $\mathbf{S}_{2}$ & $2.55 \times 10^{-4}$ & \\
\hline & $\mathbf{S}_{3}$ & $2.32 \times 10^{-4}$ & \\
\hline \multirow{3}{*}{$3 \mathrm{~m} / \mathrm{s}$} & $\mathbf{S}_{1}$ & $1.79 \times 10^{-4}$ & \multirow{3}{*}{71.12} \\
\hline & $\mathbf{S}_{\mathbf{2}}$ & $1.46 \times 10^{-4}$ & \\
\hline & $\mathbf{S}_{3}$ & $1.30 \times 10^{-4}$ & \\
\hline
\end{tabular}
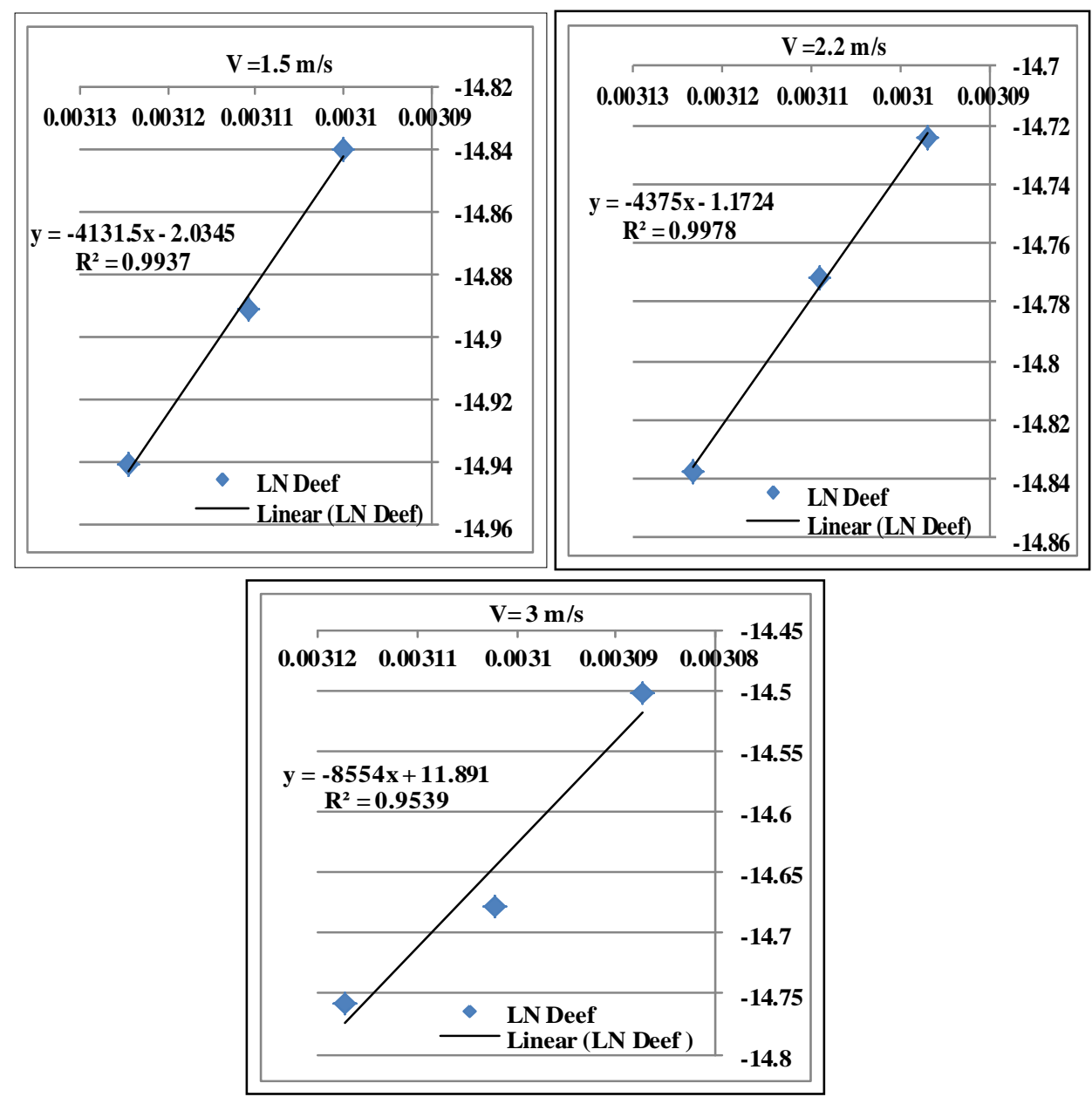

Fig. (4): Variation of effective diffusivity as function of temperature. 


\section{CONCLUSION}

1- The daily collector efficieny ranged between 13.28 to $64.49 \%$ while the dryer ranged from 2 to $37 \%$.

2 - The daily collector effectiveness ranged from 7.24 to $68.58 \%$ while the dryer ranged from 5.81 to $62.16 \%$.

3- Page,Modified page and Modified page was selected as a suitable model to drying apricots highest value of $\mathrm{R}^{2}$ and the lowest value of $\mathrm{x}^{2}$.

4- The rehydration ratio of dried apricots ranged from 2.2 to $2.9 \%$.

5- The Effective moisture diffusivity varied from $1.94708 \times 10-5$ to $3.01943 \times 10-5 \mathrm{~m}^{2} / \mathrm{s}$.

6- The activation energy varied from 34.35 to $71.12 \mathrm{~kJ} / \mathrm{mol}$.

7- It was deduced that at a low air velocity $(3 \mathrm{~m} / \mathrm{s})$ results absorption greater of moisture that leads to an increase in the moisture diffusivity.

8- the payback period for is dryer were1.22 years.

\begin{tabular}{|c|c|c|c|}
\hline \multicolumn{4}{|c|}{ Nomenclature } \\
\hline w.b & wet base & d.b & dry base \\
\hline $\mathrm{W}$ & Mass of wet sample, $\mathrm{g}$. & Ln MR & moisture ratio \\
\hline $\mathrm{Wt}+\mathrm{dt}$ & Mass of apricots at a specific $\mathrm{t}+\mathrm{dt},(\mathrm{g})$. & MR & moisture ratio \\
\hline $\mathrm{Mt}+\mathrm{dt}$ & $\begin{array}{l}\text { Moisture content at a specific } \mathrm{t}+\mathrm{dt}(\mathrm{g} \\
\text { water / } \mathrm{g} \text { solid). }\end{array}$ & $\% \mathrm{E}$ & the average percentage error \\
\hline $\begin{array}{l}\mathrm{a}, \mathrm{n} \mathrm{k}_{\mathrm{L}}, \mathrm{k}_{\mathrm{P}} \\
\mathrm{k}_{\mathrm{M}}, \mathrm{k}_{\mathrm{H}}\end{array}$ & Empirical constants in drying models $\left(\mathrm{s}^{-1}\right)$ & $\mathrm{N}$ & Number of observations \\
\hline D & Mass of dry material in the sample, $g$. & RMSE & root mean square error \\
\hline $\operatorname{Ln} \mathrm{t}$ & natural logarithm of drying time & $x^{2}$ & reduced chi-square \\
\hline $\mathrm{L}$ & thickness of the sample (slab) (m) & $\mathrm{t}$ & Drying time (min) \\
\hline MR Exp & experimental moisture ratio & $n$ & number of constants \\
\hline MR Prd & predicted moisture ratio & $\mathrm{Ea}$ & Activation energy \\
\hline MR Prd & the average predicted moisture ratio & $\mathrm{R}^{2}$ & coefficient of determination \\
\hline$D_{\text {eff }}$ & Effective moisture diffusivity $\left(\mathrm{m}^{2} / \mathrm{s}\right)$ & Qconv & converted heat (W/m2) \\
\hline $\mathrm{Mt}$ & Moisture content at time $\mathrm{t}, \%$ wb & Tabs & absolute air temperature $(\mathrm{K})$ \\
\hline Mo & Initial moisture content, $\%$ wb & $\mathrm{R}$ & $\begin{array}{l}\text { Universal gas constant }(8.3143 \\
\mathrm{kJ} /(\mathrm{kmol} . \mathrm{K}))\end{array}$ \\
\hline $\mathrm{F}_{0}$ & Fourier number for diffusion & $\mathrm{Cp}$ & $\begin{array}{l}\text { specific heat of air } 1007 \\
\left(\mathrm{~J} / \mathrm{kg}^{\circ}{ }^{\circ} \mathrm{C}\right)\end{array}$ \\
\hline $\mathrm{D}_{\mathrm{o}}$ & $\begin{array}{l}\text { Pre-exponential factor of Arrhenius } \\
\text { equation }\left(\mathrm{m}^{2} / \mathrm{s}\right) \text {. }\end{array}$ & $\mathrm{m}$ & mass flow rate of air $(\mathrm{kg} / \mathrm{s})$ \\
\hline Tout-coll & $\begin{array}{l}\text { air temperature at outlet of solar collector } \\
\left({ }^{\circ} \mathrm{c}\right)\end{array}$ & Tin-coll & $\begin{array}{l}\text { air temperature inlet solar } \\
\text { collector }\left({ }^{\circ} \mathrm{c}\right)\end{array}$ \\
\hline Tin-chamb & air temperature inlet chamber $\left({ }^{\circ} \mathrm{c}\right)$ & Ac & absorbent area $(\mathrm{m} 2)$ \\
\hline Tout- chamb & $\begin{array}{l}\text { air temperature at outlet of chamber } \\
\left({ }^{\circ} \mathrm{c}\right)\end{array}$ & $\%_{\eta} \mathrm{d}$ & The thermal dryer efficiency \\
\hline$\%_{\eta} c$ & The thermal collector efficiency & Rad & solar radiation $(\mathrm{W} / \mathrm{m} 2)$ \\
\hline $\mathrm{Eu}$ & $\begin{array}{l}\text { energy used to evaporate water in the } \\
\text { product }\end{array}$ & $\mathrm{E}_{\mathrm{A}}$ & $\begin{array}{l}\text { energy provide to the air } \\
\text { during drying }\end{array}$ \\
\hline$m a$ & Weight of air $(\mathrm{kg})$ & $\mathrm{EF}$ & energy of the fan $(\mathrm{J})$ \\
\hline
\end{tabular}


PROCESS ENGINEERING

\begin{tabular}{|c|c|c|c|}
\hline Le & $\begin{array}{l}\text { latent-heat of vaporization of moisture } \\
(\mathrm{kJ} / \mathrm{kg})\end{array}$ & me & $\begin{array}{l}\text { mass of moisture evaporated in } \\
\text { time } t\end{array}$ \\
\hline 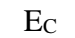 & Collector effectiveness & $E_{d}$ & Dryer effectiveness \\
\hline $\mathrm{T}_{\mathrm{amb}}$ & ambient air temperature $\left({ }^{\circ} \mathrm{c}\right)$ & $\mathrm{v}$ & air flow velocity, $\mathrm{m} / \mathrm{s}$ \\
\hline $\mathrm{w}_{\mathrm{r}}$ & weight of rehydrated sample, g. & $\mathrm{R}_{\mathrm{r}}$ & Rehydration ratio \\
\hline $\mathrm{M}_{\mathrm{i}}$ & $\begin{array}{l}\text { Moisture content of samples before } \\
\text { dehydration, } \%(\mathrm{wb})\end{array}$ & $\mathrm{W}_{\mathrm{d}}$ & weight of dry sample, g. \\
\hline $\mathrm{M}_{\mathrm{f}}$ & $\begin{array}{l}\text { Moisture content of dehydrated samples, } \\
\% \text { (wb) }\end{array}$ & & \\
\hline
\end{tabular}

\section{REFERENCES}

Akpinar, E.K., Bicer, Y., Cetinkaya, F.(2006). Modelling of thin layer drying of parsley leaves in a convective dryer and under open sun. J. Food Eng. 75, 308-315.

http://dx.doi.org/10.1016/j.jfoodeng.2005.04.018.

Akgun, N.A., Doymaz, I. ( 2005). Modeling of olive cake thin-layer drying process. J. Food Eng. 68, 455-461. http://dx.doi.org/10. 1016 /j.jfoodeng.2004.06.023.

Amer B. M. A.\& Amer Eissa,A.H.(2015) Thin layer model for solar drying of navel and minneola orane silices Misr J. Ag. Eng., October 2015 Misr J. Ag. Eng., 32 (4): 1589 - 1608.

AOAC. (2005). Association of Official Analytical Chemists, Official Methods of Analysis (18th Ed.). International, Maryland, USA.

Basunia, M. A., \& Abe, T. (2001). Thin-layer solar drying characteristics of rough rice under natural convection. Journal of Food Engineering,47, 295-301.

Brennand, C.P.(1994).Home drying of food. August 1994 (FN-330) http://extension.usu.edu/files/publications/publication/FN-330.pdf.

Bruce, D.M., (1985). Exposed layer barley drying, three models fitted to new data up to 150oC. J. Agric. Eng. Res., 32: 337-347.

Can A. (2000) Drying kinetics of pumpkin seeds. Int J Energy Res;24:965-75.

Celma, A.R., Rojas, S., Lopez-Rodriguez, F.(2008). Mathematical modelling of thinlayer infrared drying of wet olive husk. Chem. Eng. Process. 47, 1810-1818. http: // dx.doi.org / 10.1016/j.cep .2007.10.003.

Crank J. (1975): Mathematics of diffusions. Oxford University Press, London. 
Diamante, L.M. and Munro, P.A. (1991). Mathematical modeling of hot air drying of sweet potato slices. Int. J. Food Sci. Technol., 26: 99.

Donka,I., Nikolay,V., Irena,V., Darina,S.(2017) Optimization of Convective Drying of Apricots. TEM Journal. Volume 6, Issue 3, Pages 572-577.

Doymaz I. (2007): Air-drying characteristics of tomatoes. Journal of Food Engineering, 78: 1291-1297.

Edoun M., Boroze T., Kuitche A., Giroux F.( 2013) Optimization of the design and drying process adapted topPineapple slices. Journal of Food Science and Engineering. 3, 609-615.

Fadhel, A., Kooli, S., Farhat, A. and Belghith, A. (2014). Experimental study of the drying of hot red pepper in the open air, under green house and in a solar drier. International Journal of Renewable Energy \& Biofuels

Gunhan, T., V. Demir, E. Hancioglu and Hepbasli,A. (2005). Mathematical modeling of drying of bay leaves. Energ. Conser. Manage., 46(11): 1667-1669.

Hassan, M.M.A. (2015). Solar drying performance study of some crops (mint, okra and grapes) I- assessing the drying rates. Misr J. Of Ag. Eng., 32(1):205-222.

Henderson, S.M. \& Pabis,S. (1961).Grain drying theory. II. Temperature effects on drying coefficients. J.Agric. Eng. Res., 6: 169-174.

Kudra T. (2004) Energy Aspects In Drying. Drying Technology, 22 (5), 917-932.

Kutscher, C.F., Christensen, C., Barker, G., 1993. Unglazed transpired solar collectors: heat loss theory. ASME Journal of Solar Engineering 115 (3), 182-188.

Maskan, M. 2001. Drying, shrinking and rehydration characteristic of kiwi fruit during hot air and microwave drying. J. Food Eng. 48, 177-182.

Milczarek, R., AvenamM., Alonzo j., Fichot, M.(2014) Improving the Sun Drying of Apricots (Prunus armeniaca) with Photo-Selective Dryer Cabinet Materials.Food Sci.Oct;81(10):E2466-E2475.

Mrittika, B. , Prem, P. S. \& Hari, N. M.(2000). Thin-layer modeling of convective and microwave-convective drying of oyster mushroom 
(Pleurotus ostreatus). Journal of Food Science and Technology Mysore- . December (India) DOI 10.1007/s13197-013-1209-2. https://www.researchgate.net/publication/259024701

Neufville, R.(1990). Applied Systems Analysis. McGraw-Hill Publishing Company, New York, USA

Page, G.E.,(1949). Factors influencing the maximum rates of air drying shelled corn in thin layers. M.S. Thesis, Department of Mechanical Engineering, Purdue University, purdue, USA.

Purohit, P., Kumar, A., Kandpal, T.C., 2006. Solar drying vs. open sun drying: a framework for financial evaluation. Solar Energy 80, 15681579.

Premi, M.; Sharma, H.K.; Sarkar, B.C. and Singh, C. (2010). Kinetics of drumstick leaves (Moringa oleifera) during convective drying. African Journal of Plant Science, 4 (10): 391-400.

Sanjuan, N., Lozano, M., Garcia-Pascal, P., Mulet, A.(2003). Dehydration kinetics of red pepper (Capsicum annuum L. var. Jaranda). J. Sci. Food Agric. 83, 697-701.

Shi, Q., Zheng, Y., \& Zhao, Y. (2013). Mathematical modeling on thinlayer heat pump drying of yacon (Smallanthus sonchifolius) slices. Energy Conversion and Manage, 71, 208-216.

Tayel, S. A.; T.H. Ghanem; A. A. El-Messery and . Badr, M. M (2012). Modeling A Microwave/Convection Dryer for Drying of Potato Slices. Misr J. Ag. Eng., 29 (4): 1377 - 1398.

White, G.M., I.J. Ross and Ponelert, R. (1981). Fully exposed drying of popcorn. Tran. ASAE, 24: 466-468.

Yilbas, B.S., Hussain, M.M., Dincer, I.(2003) Heat and moisture diffusion in slab products to convective boundary condition. Heat Mass Transfer. 39, 471-476.

http://dx.doi.org/10.1007/s00231-002-0323-x.

Zogzas N.P., Marulis Z.B., Mariinos-Kourisd (1996):Moisture diffusivity data compilation in foodstuffs. Drying Technology, 14: 2225-2253.

Zhengfu W, Junhong S, Xiaojun L, Fang C, Guanghua Z, Jihong W, Xiaosong H (2007)Mathematical modeling on hot air drying of thin layer apple pomace. Food Res Int 40:39-46 


\section{الملخص العربي}

\section{تصنيع مجفف شمسى غير مباشر من مواد محلية لتجفيف المشمش الثربع}

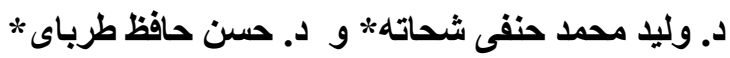

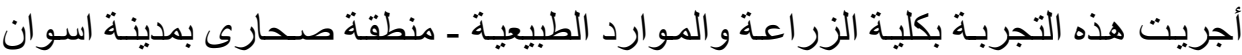

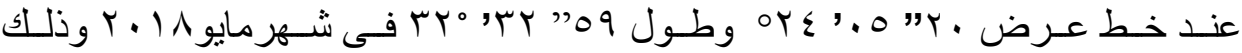

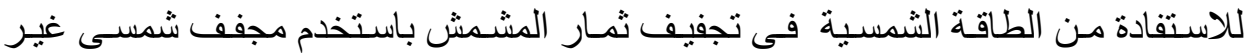

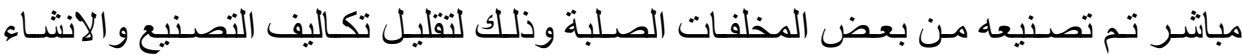

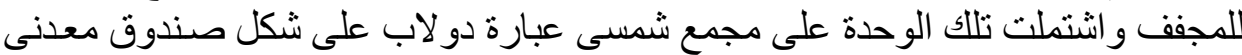

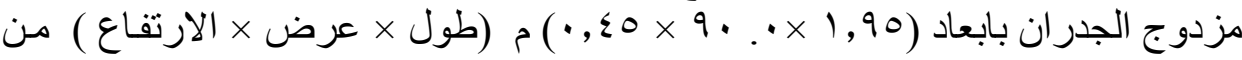

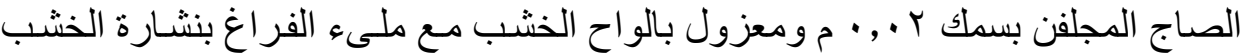

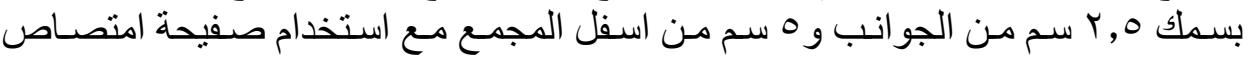

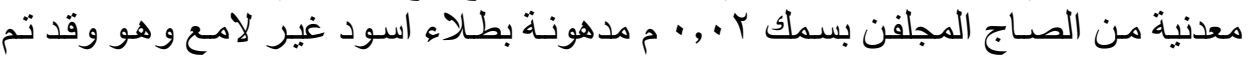

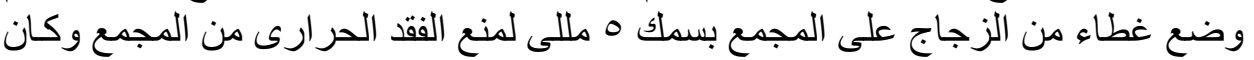

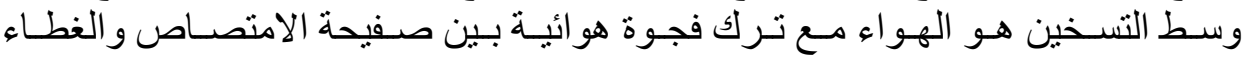

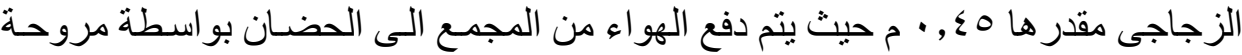

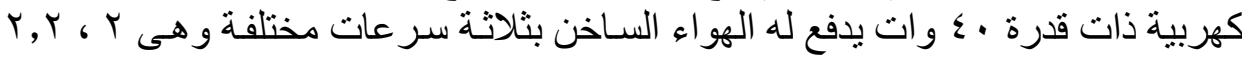

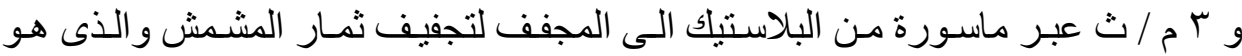

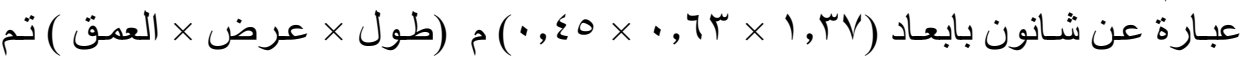

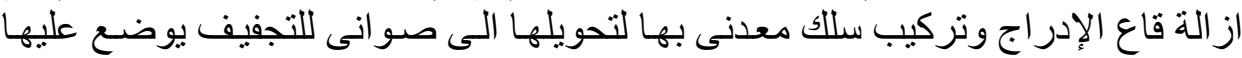
ثمار المشمش بعد از الة النواة وهو عبارة عن صندوق معدنى مزدوج الجدران من الصـاج

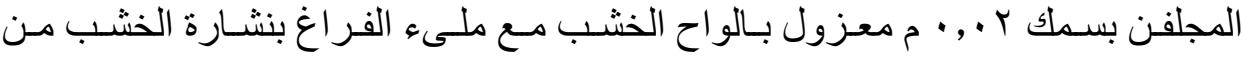

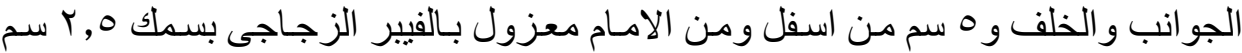

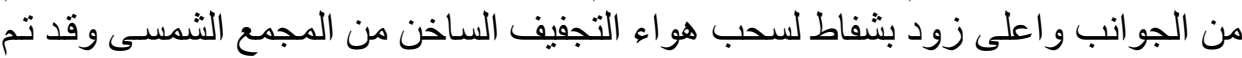

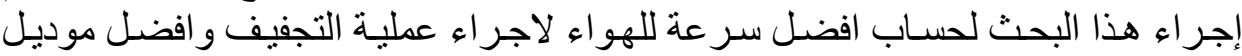
تجفيف حيث يكون R اكبر ما يمكن و X اصغر ما يمكن وكذلك حسـاب كفاءة وفاعلية كلا من المجمع الثمسى و المجفف وفاعلية الانتشار الرطوبى ماهن و طاقة التفعيل.

و قد تبين من النتائج المتحصل عليها كل مما يأتي :

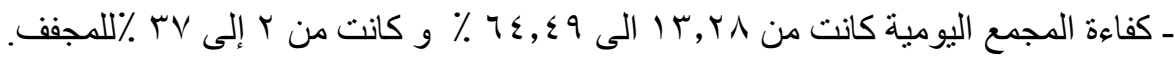

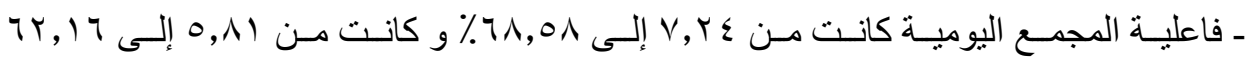
\% للمجف.

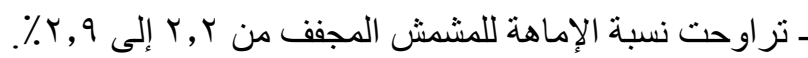

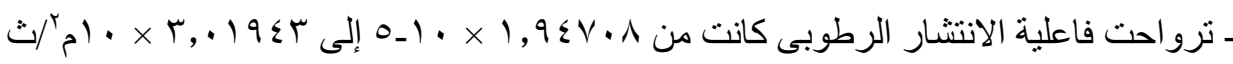

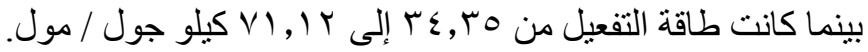

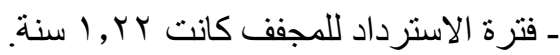

